Division of Geological \& Geophysical Surveys

PUBLIC-DATA FLLE 99-24a

\title{
PRELIMINARY GEOLOGIC MAP OF THE HEALY A-6 QUADRANGLE, SOUTHCENTRAL ALASKA
}

\author{
by \\ K.H. Clautice, R.J. Newberry, \\ R.B. Blodgett, T.K. Bundtzen, B.G. Gage, E.E. Harris, S.A. Liss, M.L Miller, D.S. Pinney, R.R. Reifenstuhl, \\ J.G. Clough. D.B. Stone, and M.T. Whalen
}

August 1999

THIS REPORT HAS NOT BEEN REVIEWED FOR TECHNICAL CONTENT (EXCEPT AS NOTED IN TEXT) OR FOR CONFORMITY TO THE EDITORIAL STANDARDS OF DGGS.

Released by

STATE OR ALASKA

DEPARTMENT OP NATURAL RESOURCES

Division of Geological \& Geophysical Surveys

794 University Avenue, Suite 200

Fairbanks, Alaska 99709-3645

Research supponed by the U.S. Geologieal Survey, Nasional Coopersive Geologic Mapping Program, under USCS award number 98HQAG2083. The vlews and conclusions conlajned in this document are those of the authors and should not be interprescd as accessarily representing the official policies either expressed or implied. of tho U.S. Coverimens. 


\title{
PRELIMINARY GEOLOGIC MAP OF THE HEALY A-6 QUADRANGLE, SOUTH- CENTRAL ALASKA
}

\author{
by \\ K.H. Clautice', R. N. Newberry ${ }^{2}$ \\ R.B. Blodger', T.K. Bundtzen', B.G. Gage², E.E. Hanris², S.A. Liss², M.L. Miller', R.R. Reifenstuhl'2, \\ D.S. Pinney', J.G. Clough', D.B. Stone', and M.T. Whalen'
}

\section{GEOLOGIC BACKGROUND}

The Healy A-6 (1:63,360-scale) Quadrangle forms the core of the Chulitna mining district that was geologically mapped by the Alaska Division of Geological \& Geophysical Surveys (DGGS) over a period of about six weeks during the 1997 and 1998 field seasons. This work followed recent airborne geophysical surveys (magnetic and resistivity) of the district (DGGS, 1997a,b,c,d; Burns, 1997) Because many of the bedrock units in the district have distinctive geophysical signatures, the airbome surveys proved to be extremely useful mapping tools to delineate both map units and structure, particularly in areas of extensive surficial cover. Additional DGGS reports that resulted from this study of the Chulitna mining district relate to interpretive bedrock geology (Clautice and others, 1999), Quaternary and engineering geology (Pinney, 1999a,b), major and trace element rock chemistry (Gage and others, 1998), fossil localities (Blodgen and Clautice, 1999), radiolarians (M.Z. Won and others, 1999), and a paleomagnetic report (Stone and others, 1999).

The geology and mineral deposits of the Upper Chulitna district were first described in detail in a series of papers by Hawley and others (1968, 1969), Hawley and Clark (1973, 1974), and Clark and Hawley (1972). Jones and others (1980) interpreted the geology of the district to represent six allochshonous terranes, including an ophiolite assemblage. Rock ages in their repor were established with extensive micro- and macro-fossil identifications. Csejtey and others (1992) published a compilation of the geology of the Healy Quadrangle, which showed the Chulima district to comprise a series of allochthonous stacked blocks thrust from the north over a basement of Cretaceous melange. Regional geology of south-central Alaska is summarized in a paper by Nokleberg and others (1994).

Early workers in the district included Brooks (1911), Moffit (1915), and Capps (1919). Ross (1933) recognized fault-controlled mineralization, volcaniclastic rocks, and several major faults. Wahrhaftig described area coal deposits (1944) and engineering geology along the nearby Alaska Railroad (1958). Mulligan and others (1967) published a report on sampling of the Golden Zone mine.

\section{GEOCHRONOLOGY}

\section{METHODS}

Twenty-seven rocks from the study area were prepared for ${ }^{40} \mathrm{Ar}{ }^{39} \mathrm{Ar}$ dating through preparation of monomineralic separates of appropriate K-rich minerals. After irradiation, the mineral separates were analyzed by step heating, using a 6 watt argon-ion laser, as described in Layer and others (1987). On average, 12-16 fractions were collected for each sample. Samples of homblende MMMbl (Samson and Alexander, 1987) with an age of 513.9 Ma were included with each set of unknowns to monitor the neutron flux. Each gas fraction was analyzed for Ar isotopic ratios in a VG-3600 mass spectrometer at the Geophysical Institute, University of Alaska Fairbanks. The argon isotopes measured were corrected for system blank and mass discrimination, as well as calcium, potassium and chlorine interference. Apparent ages and 1 sigma uncertainties were calculated for each fraction using the constants of Steiger and Jaeger (1977).

\footnotetext{
'Alaska Division of Geological and Geophysical Surveys, 794 University Ave., Suite 200, Fairbanks, Alaska 99709-3645

'University of Alaska Fairbanks, Department of Geology \& Geophysics. P.O. Box 755780, Fairbanks, Alaska 99775-5780

${ }^{1} 1025$ NW $26^{\star}$ Street, Corvallis Oregon 97330

'DGGS at ime of field mapping; now with Pacific Rim Geological Consulting, P.O. Box 81906, Fairbanks, AJaska 99708

${ }^{5}$ U.S. Geological Survey, 4200 Universiry Drive, Anchorage, Alaska 99508
} 
For each sample the "integrated age" (she weighted average of each fraction age) was calculated to facilitate comparison with previously determined $\mathrm{K}-\mathrm{Ar}$ ages. Where three or more consecurive heating steps yielded the same age ( $t$ I sigma), which accounted for more than 50 percent of the released Ar, the weighted average of these steps was calculated as the "plateau age." Where significant isotopic variations occurred between individual steps, an isochron age was calculated from the ${ }^{10} \mathrm{Ar} /{ }^{34} \mathrm{Ar}$ and ${ }^{40} \mathrm{Ar} /{ }^{36} \mathrm{Ar}$ ratios. This age was considered significant only if the Mean Square Weighted Deviation (MSWD) was <2.5. For several samples, the last 10 percent or so of gas release yielded an age significantly older than the plateau or isochron age. Because such ages reflect a phase or domain that was less affected by Ar diffusional loss than the bulk of the mineral, they are both indicators of complex thermal history and yield minimum ages of mineral formation. In many such cases, while the Ar spectrum technically satisfied the criteria for a plateau, increasingly older ages for fractions released at increasing temperature ("pseudo plateau") also indicate that the "plateau" age is not a valid measure of the true age.

Lacking anomalous ages for either the higher-or lower-temperanure fractions, the interpreted age of the sample was taken to be the isochron (preferred) or plateau age. If neither a plateau nor an isochron (with an MSWD $<2.5$ ) could be generated from the step-release heating, then the integrated age was caken as a minimum estimate of the age of mineral formation or re-heating. Where a clearly defined, anomalously old, high-temperarure fraction age was determined, this age was taken as a minimum age.

\section{RESULTS}

The results of the step-heating Ar measurements, summarized in Table $l$, indicate that most of the rocks examined experienced complex thermal histories. In particular, all the pre-Jurassic rocks sampled experienced partial to complete Ar loss, indicared by plateau and isochron ages of 145 to $65 \mathrm{Ma}$ (table 1). Because Late Cretaceous igneous rocks are limited to small stocks and dikes, this extensive degree of re-heating requires that major igneous bodies of Late Cretaceous age must underlie the Chulitna region. This, in conjunction with the major igneous intrusions in the structural blocks east and west of the Chulitna block, indicate major vertical movements along the high-angle faults bounding the Chulitna block (fig. 1).

The intrusive rock ages also show that some previous age assignments are incorrect. In particular, all mafic intrusions in the region were previously assigned a Tertiary age (Hawley and Clark, 1974); this snidy (table 1) shows that some are Tertiary $(98 \mathrm{KC} 124)$, some are Late Cretaceous (97RN336), and some are pre-Cretaceous (97RN438). In particular, because pre-Cretaceous mafic intrusions represented by sample 97RN438 (minimum age of $179 \mathrm{Ma}$ ) are compositionally indistinguishable from basalt flows interlayered with Late Triassic megafauna (unit Trlb), it is most likely that these intrusions are also of Late Triassic age. Further, since such intrusions cut unit TrPvs ("red beds" of Jones and others, 1990), unit TrPvs must be older than unit Trlb, and not younger (as inferred by Jones and others, 1990). Such age relationstips have vital importance with respect to structural interpretations in the A-6 quadrangle, indicating that many of the thrust faults inferred by Jones and others (1990) are not present.

Tertiary intrusions also caused thermal resets, however, as indicated by disturbances in spectra of several Late Cretaceous plutons and dikes (table 1). Igneous and contact metamorphic rocks from the Partin Creek prospect, for example, yield plateau ages of 76,71 , and $68 \mathrm{Mr}$. Further, the samples yielding younger plateau ages also gave high-temperature fractions with ages significantly older than the plateau age, indicating post-Cretaceous thermal disturbance. Such results indicate that interpreted ages of Late Cretaceous mineralization and igneous rocks must be viewed with the potential for later thermal resets in mind.

Conventional K-Ar dates previously determined for the large granite intrusion barely in the southeast comer of the A-6 quadrangle indicated an Early Tertiary age (Csejtey and others, 1986). Our samples (97RN507, 98HA11; table 1) also yielded Early Tertiary infegrased (= K-Ar equivalent) ages, but Late Cretaceous pseudo plateau and high-temperature fraction ages indicate it is instead of Late Cretaceous age. This result has important regional implications, as it demonstrates that not all of the so-called "McKiniey age" granites (based on K-Ar ages or general appearance) are of Early Tertiary age. Further, since "McKinley age" granites are generally considered favorable for Sn-Ag deposits, but unfavorable for Au deposits (for example, Light and others, 1990) the lode gold potential for the region is likely underestimated. 
Table 1. ${ }^{40}$ Ar ${ }^{39}$ Ar age data for the Healy A-6 Quadrangle and vicinity

\begin{tabular}{|c|c|c|c|c|c|c|c|c|}
\hline $\begin{array}{l}\text { Sample } \\
\text { Number }\end{array}$ & Unit & $\begin{array}{r}\text { Lou } \\
\text { Langitud } \\
\end{array}$ & Lation & Rock type & Minera!b & $\begin{array}{l}\text { Interpreted } \\
\text { Age (Ma)c }\end{array}$ & $\begin{array}{l}\text { Integrated } \\
\text { age (Ma)d }\end{array}$ & Commentse \\
\hline 97AM222 & uPZt & -149.6578 & 63.1568 & Metatuff breccia & Amphts & $>70 \pm 1.5(\bar{h})$ & $61.3 \pm 0.5$ & Pseudo plateau $\approx 65 \mathrm{Ma}$; reset $35 \pm 5 \mathrm{Ma}$ \\
\hline 97BT200 & $\operatorname{TrP}_{\mathrm{vs}}$ & -149.6455 & 63.1993 & Retrograde skaru & Ho & $>59 . \overline{9} \pm 0.3$ & $60.2 \pm 0.3$ & Copper King prospect-Good plateau, bu ClK spectrum suggests resel \\
\hline $97 \mathrm{KC281}$ & $\mathrm{Km}$ & -149.9567 & 63.0714 & Quartz monzodiorite & $\mathrm{Bi}$ & $67.8 \pm 0.3$ & $67.6 \pm 0.3$ & Partin Creek Prospect-Gighesi.T fraction $70 \pm 2 \mathrm{Ma}$ \\
\hline $97 \mathrm{KC} 301$ & TRs & $\cdot 150.0008$ & 63.0489 & Quartz diorite dike & Ho & $68.0 \pm 0.3$ & $68.6 \pm 0.3$ & $\begin{array}{l}\text { Near Eldridge Glacier prospect-Isochron } 67.4 \pm 0.3 ; \text { High T age } 74 \pm 5 \\
\text { Ma }\end{array}$ \\
\hline $97 \mathrm{KC} 339$ & TRs & -149.9309 & 63.0890 & Altered porphyry dike & WR & $58.6 \pm 0.2(1)$ & $58.6 \pm 02$ & $\begin{array}{l}\text { Kennicolt prospect-Reset } \approx 55 \mathrm{Ma} \text {; no plateau or isochron; age probably } \\
>59 \mathrm{Ma}\end{array}$ \\
\hline $97 \mathrm{KC} 360$ & TR1b & -149.9567 & 63.0714 & Altered homfels & $\begin{array}{l}\text { Bi } \\
\text { Mu }\end{array}$ & $\begin{array}{l}75.5 \pm 0.4 \\
70.9 \pm 0.5\end{array}$ & $\begin{array}{l}67.9 \pm 0.4 \\
67.7 \pm 0.6\end{array}$ & $\begin{array}{l}\text { Partin Creek Prospect-Pseudo plateau, altered spectra, excess age? } \\
\text { Partin Creek Prospect-Pseudo plateau; reset at } \approx 30 \mathrm{Ma}\end{array}$ \\
\hline 97RN330C & $\mathrm{TrP}_{\mathrm{Ys}}$ & -149.5530 & 63.2581 & Skam & Ho & $63.7 \pm 0.3$ & $63.3 \pm 0.4$ & Silver King-Good plateau; reset at $-40 \pm 10$ Ma Healy B- 6 \\
\hline 97RN334 & $\mathrm{K} ? \mathrm{~g}$ & -149.4768 & 63.2450 & Granite dike & Ksp & $6 \mathrm{t} .4 \pm 0.3$ & $61.5 \pm 0.3$ & $\begin{array}{l}\text { Healy B-5, VABM Bult-Good plateau, but Kspar ages are }<\text { magmatic } \\
\text { age }\end{array}$ \\
\hline $97 \mathrm{RN} 336$ & $\mathrm{Km}$ & -149.6281 & 63.1903 & Alkalic? dike & Ho & $66.7 \pm 0.9$ & $68.0 \pm 1.1$ & Good plateal, fair precision \\
\hline $97 \mathrm{RN} 348 \mathrm{C}$ & $\mathrm{Tg}$ & -149.9212 & 63.1844 & Greisen & Mu & $55.0 \pm 0.2$ & $55.4 \pm 0.3$ & Ohio Creek prospect-Good plateau \\
\hline $97 \mathrm{RN} 377 \mathrm{~K}$ & $\mathrm{Kg}$ & -149.6443 & 63.1991 & Altered granile porphyry & $\mathrm{Bi}$ & $66.2 \pm 0.4$ & $63.8 \pm 0.3$ & Copper King core-Ar loss $\sim 30 \mathrm{Ma}$, model age $\approx 67 \mathrm{Ma}$ \\
\hline $97 \mathrm{KN} 398$ & Dv & -149.7518 & 63.1309 & Mela-andesite flow & Amph & $68 \pm 2.4(i)$ & $\begin{array}{l}106 \pm 9 \\
79.4 \pm 1.3\end{array}$ & Secondary (?) actinolitic amphibole; isochron represents reset age \\
\hline 97RN407D & TrPvs & -149.7711 & 63.1330 & Andesile sifl & Pyx & $>177$ (I) & $\begin{array}{l}199 \pm 352 \\
177 \pm 24\end{array}$ & Very poor precision; significant Ar loss; isachron at $145 \pm 15=$ reset age? \\
\hline $97 R N 408 B$ & $\mathrm{~K}_{\mathrm{n}}$ & -149.7877 & 63.1664 & Diorite pluton & $\mathrm{Bi}$ & $>70.6 \pm 1.6(\mathrm{~b})$ & $66.3 \pm 0.3$ & $\begin{array}{l}\text { Silver Kitty Prospect-Pseudo plateas at } 66.4 \pm 0.3 \mathrm{Ma} \text {; high } T \text { fraction } \\
\text { mostly homblende }\end{array}$ \\
\hline $97 \mathrm{RN} 438$ & TRb & -149.8082 & 63.1414 & Gabbro body & Pyx & $>179(\mathbf{0})$ & $179 \pm 7$ & Ar loss; isochron at $117 \pm 5=$ reset age? \\
\hline $97 \mathrm{RN} 495 \mathrm{C}$ & $\mathrm{Km}$ & -149.8642 & 63.1197 & Biotite diorite & $\mathrm{Bi}$ & $66.8 \pm 0.3$ & $66.8 \pm 0.3$ & Good platean; no loss. \\
\hline 97RN507A & $\mathrm{K}_{\mathbf{g}}$ & -149.4896 & 63.0160 & Granite pluton & $\mathrm{Bi}+\mathrm{Ho}_{0}$ & $>65 \pm 0.7(\mathrm{~h})$ & $\begin{array}{l}51.6 \pm 0.7 \\
54.6 \pm 1.1\end{array}$ & $\begin{array}{l}\text { High T fraction mostly homblende; At loss } \approx 20 \mathrm{Ma} \text {; pseedo plateau at } \\
64.2 \pm 1.4 \mathrm{Ma}\end{array}$ \\
\hline 97RN513A & Trlb & -149.8537 & 63.1480 & Mineralized homfels & Ho & $57.6 \pm 0.6$ & $54.8 \pm 0.7$ & Ready Cash-High $\mathrm{T}$ fraction $67.7 \pm 7.0 \mathrm{Ma}$; resct $32 \mathrm{Ma}$ \\
\hline 97RR146C & $\mathrm{Tg}$ & -149.6997 & 63.1466 & Granite dike & $\mathrm{Bi}$ & $46.0 \pm 0.3$ & $45.9 \pm 0.3$ & Good plateau; no obvious reset \\
\hline $97 \mathrm{SL} 399 \mathrm{~B}$ & $\mathrm{Km}$ & -149.6526 & 63.2394 & Mafic dike & Ho & $66.8 \pm 0.3$ & $66.9 \pm 0.4$ & Blind Creek-High T fraction $69 \pm 4 \mathrm{Ma}$; sligh hump \\
\hline 98BG149 & Kun & -149.6501 & 63.2137 & Biotite monzodionite & $\mathrm{Bi}$ & $69.3 \pm 0.6$ & $68.0 \pm 0.6$ & $\begin{array}{l}\text { Golden Zone deposit-Model age } 69.4 \text { with reset } \approx 23 \mathrm{Ma} \text {; similar } \\
\text { isochron age }\end{array}$ \\
\hline $98 \mathrm{BGl} 61$ & $\mathrm{Km}$ & -149.6501 & 63.2137 & Biotite & $\mathrm{Bi}$ & $70.1 \pm .9(i)$ & $67.4 \pm 0.6$ & Golden Zone deposit-Pseudo plateau at $70 \pm 5 \mathrm{Ma}$; zero-age resel \\
\hline 98HAII & $\mathrm{Kg}$ & -149.4858 & 63.0094 & Granite & $\mathrm{Bi}$ & $>71$ & $49.8 \pm 0.4$ & loss $\approx 16 \mathrm{Ma}$; psendo platean at $66.5 \pm 1 \mathrm{Ma}$ \\
\hline 98HA55B & Dv & $-149,3273$ & 63.2670 & Honfelsed volcanic & $\mathrm{Bj}$ & $72.7 \pm 0.4(i)$ & $70.5 \pm 0.3$ & $\begin{array}{l}\text { Hetly BS, T19S R9W S17 Complex age spectram; similar plateau age; } \\
\text { resel } \approx 25 \mathrm{Ma}\end{array}$ \\
\hline $98 \mathrm{KCl} 24$ & $\operatorname{Tm}$ & -149.4833 & 63.0321 & Diabase dike & Ho & $52.4 \pm 0.2$ & $51.4 \pm$ & Healy A 5 -Complex spectra: reset $\approx 35-40 \mathrm{Ma}$ \\
\hline 98RN50G & Pl & -149.6217 & 63.2318 & Skan & Ho & $69.9 \pm 0.9$ (i) & $71,2 \pm 0.8$ & Complex age spectum; similar platean age \\
\hline $\mathrm{CC} 36-659$ & $T_{\mathrm{g}}$ & -149.8611 & 62.9928 & Sn-greisen & Mu & $\$ 3.4 \pm 0.2$ & $53.7 \pm 0.2$ & Talkeetna Mounteins D-6, Coal Creek tin deposit-Platean = isochron age \\
\hline
\end{tabular}

Analyses perfomed by P. Layer and J. Drake, University of Alaska Geochronology Lab, Geoplysical Institute, University of Alaska, Fairbanks, Alaska.

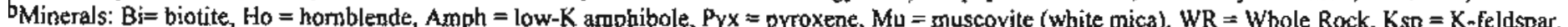

cUnless noted otherwise, intenpreted ages are plateau ages: I = Integrated age, $\mathrm{i}=$ isockron age, h= age of highest-temperature fraction (minimum age). Ages reponed at $\pm \mathrm{I} \sigma$.

dEquivalent to a conventional K-Ar age, and given for comparison purposes only.

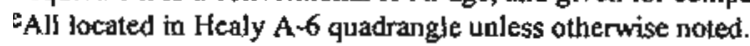




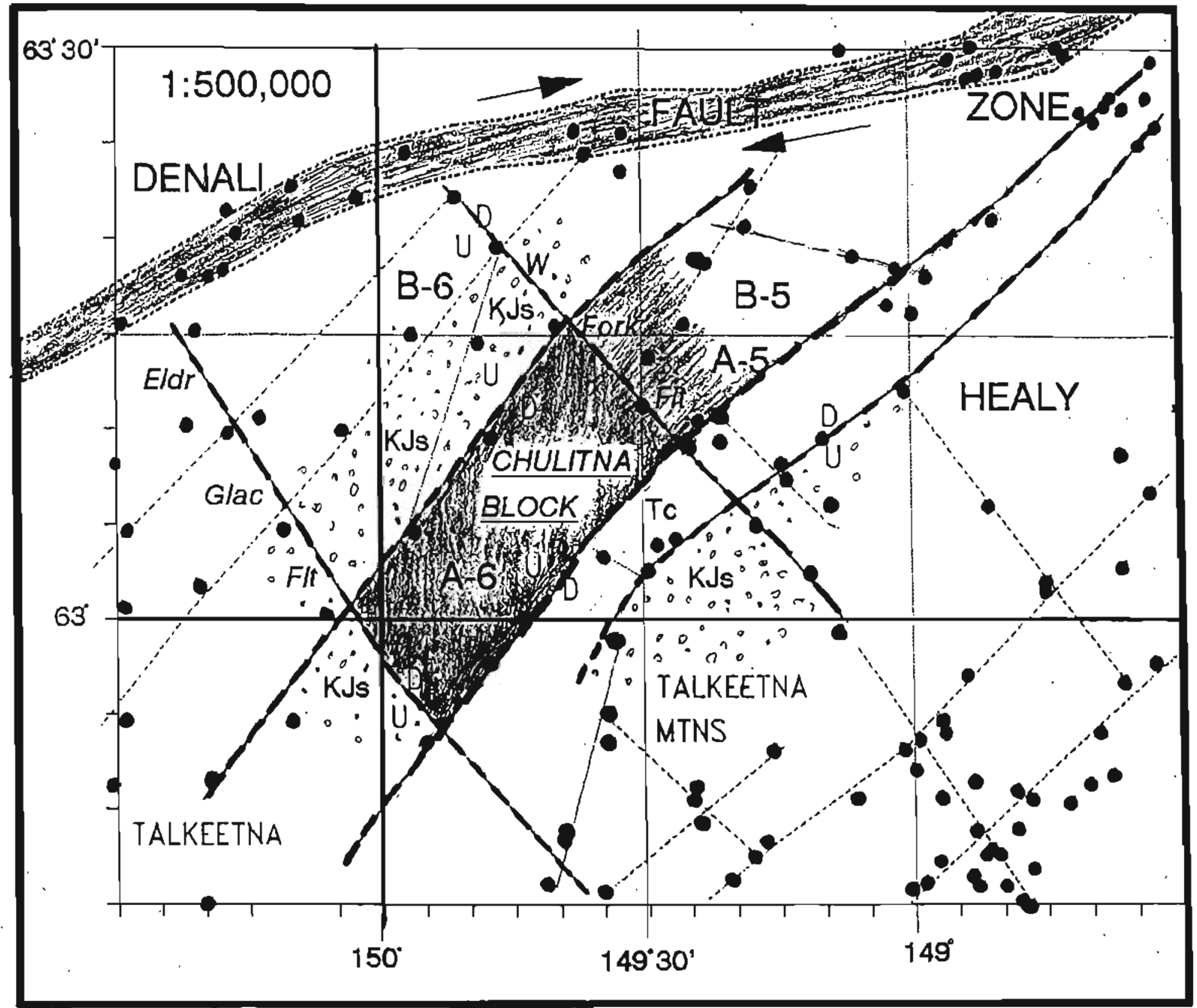

Fig. 1. Simplified structural maps of the SW Healy quadrangle and vicinity, show interpreted high-angle fauls and shallow earthquake epicenters (solid dots) for 1990-1996. High-angle faults that bound major sructural blocks in he Healy A- 6 quadrangle are shown in bold. Because the earthquake foci are up to $20 \mathrm{~km}$ below the surface, and the associated faults have dips of 75-85 (i.e., are not strictly vertical), a given epicenter can be located up to $5 \mathrm{~km}$ down-dip from the surface trace of the associated fault. Earthquake epicenter and focal depth data courtesy of the U.S. Geological Survey, Alaska Earthquake Information Center. 


\section{STRUCTURE}

The dominant structures in the Healy A-6 Quadrangle are high-angle faults (fig. 1), as indicated by linear patterns of shallow earhquake epicenters. Early workers (for example, Hawley and Clark, 1974) mapped these as high-angle faults because their nearly straighi-line surface traces show no deflection by the $>2 \mathrm{~km}$ ropographic relief. Subsequent workers (Jones and others, 1990; Csejtey and others, 1978) mapped these as (moderate- to highangle) thrust faults to accommodate their geologic model of terrane collision. However, abrupt breaks on aeromagnetic maps that correspond with linear zones of high conductivity and to the traces of these faults indicates they are very steeply dipping.

There appear to be three major orientations to high-angle faults in the region: northeast, northwest, and northnortheast (fig. 1). The most continuous faults, and those with apparently greatest displacements are the northeasttrending ones. These define the Broad Pass graben and the northwestern margin of the Paleozoic ("Chulima") block. We have no direct evidence for the amounts of horizontal movement, but the vertical displacements must be greater than a kilometer. The orientations of this set suggest that they are related to the Denali fault, and thus may have significant horizontal movement.

The second most important fault ses are the northwest-trending faults, which occur with an apparent spacing of approximately $20-30 \mathrm{~km}$, and a geometry apparently conjugate to the northeast-trending set. Apparent horizontal and vertical offsets of a few kilometers are likely. Veins and dikes are commonly oriented parallel to the northeasttending faults, and less-commonly parallel to the northwest-trending faults. Such evidence suggests that this faulting began by approximately $70 \mathrm{Ma}$.

The most abundant faults, but with smallest apparent offset, are the north-norheast-trending set. Earthquake epicenters appear to outline only a few of these (fig. 1), although their topographic expression and minor movement would suggest they are of recent origin. These faults appear to have largely strike-slip movement of less then a few kilometers and eruncate against the major, block-defining, northeast-trending faults. A young age is also indicated by the fact that these faults offset veins, skams, and mineralized plutons. Tracing mineralization pastems is severely complicated by these younger faults.

Several sets of structures pre-date these young, high-angle faults; it is difficult to define or trace these older structures, however, due to the younger fault movements. Although there is no direct evidence for low-angle faults in the Healy A-6 Quadrangle, indirect evidence suggest that the Paleozoic Chulitna block sits structurally above the extensive KJs unit along a low-angle fault surface. The most striking evidence comes from the Late Cretaceous and Early Tertiary intrusive rocks in the region. Such intrusions cut all pre-Tertiary rocks in the region, but their outcrop sizes vary dramatically between the major fault blocks. Intrusions with indistinguishable ages and compositions occur as large plutons to batholith-sized bodies in unit $\mathrm{KJ}$ s, but as dikes or small plugs within the Paleozoic block. Given that the intrusions into $\mathrm{KJ}$ commonly occur at higher present elevations than the dikes and plugs in the Chulitna block, these differences can be mosi readily ascribed to major, post-intrusive uplift of KJs blocks relative to the Paleozoic blocks. Such a relationship, in turn, requires that the Paleozoic rocks are structurally above KJs, hence in thrust contact

The major structural style within the Chulitna block is a series of northeast- to north-northeast-plunging, right, overnurned folds, with both limbs dipping to the northwest. Fold wavelength is approximately $1-2 \mathrm{~km}$, and becomes tighter towards the center of the block. Folds in the central part apparently involve the oldest units and are cored by irregular pods of partly serpentinized mafic/ultramafic rocks and serpentinite. Southeast of the strongly folded part are poorly exposed units consisting of weakly metamorphosed wfffs and sediments, within which lack of detailed stratigraphy has not allowed mapping of folds. Similarly, northeast-trending folds were not mapped in the KJs units northwest of the Chulitna block, although the lenticular distribution of subunits is consistent with the presence of relatively tight, commonly isoclinal, folds. This folding most likely accompanied structural emplacement of the Chulitna biock, as the folds are cut by undeformed plutons and high-angle faults.

In summary, we infer the structural style of the Chulitna block (units Pvs through TRs) to be a tightly folded stratigraphy thnst and overturned from the south, and subsequently cut by extensive high-angle fault systems. Faulting is dominated by a large northeast-trending graben, or down-dropped block, through Broad Pass in which Tertiary gravels have been preserved. Vertical faults parallel to the graben occur on either side of Broad Pass. Vertical movement between northeast-trending blocks controls the level of mineralizing plutons and thus surface expressions of mineralization in the region. 


\section{ECONOMIC GEOLOGY}

by R.3. Newberry

The only recorded metal production from the Healy A-6 Quadrangle is from the Golden Zone deposit. Between 1941 and 1942 it produced 1,581 oz Au. $8.617 \mathrm{Oz} \mathrm{Ag,} 21$ tons $\mathrm{Cu}$, and 1.5 tons $\mathrm{Pb}$ from 1,730 tons of ore. A small amount of placer gold was mined from $8 r$ n Mawr Creek, immediately downstream from the Golden Zone, and from McCallie Creek, in the westem part of the quadrangle. Field descriptions and assay data for major prospects are given in Hawley and Clark (1974), Kurtak and others (1992), and Gage and others (1998).

Stratiform, syngenetic/diagenetic deposits appear to be rare or non-existent in the Healy A-6 Quadrangle. Although volcanic rocks evidently erupted into aqueous environments are common in the A- 6 quadrangle, there is no evidence for submarine hydrothermal activity nor for volcanogenic massive sulfide deposits. Because the Permo-Triassic unit (TrPvs) formerly referred to as "sedimentary redbeds" (Jones and others, 1990) consists principally of iron-rich, mafic volcaniclastic rocks and associated sediments, and is not a "redbed" in the commonly accepted sense of a hemaritic sandstone, there is no likelihood of redbed-associated Cu deposits in this unit. Basalthosted and basalt-overlain $\mathrm{Cu}$ deposits. which are common in-and stratigraphically above-Late Triassic basalts elsewhere in the northwest Cordillera, are only present in areas with thick accumulations of subaerial basalt (Mackevett and others, 1997). As the equivalent basalt units in the A-6 quadrangle are thin and interbedded with carbonate rocks, this mineralization style is also unlikely in the area. Placer gold accumulations are not significant, as the area has been eroded by multiple glaciation events in the recent past.

Very small bodies of chromite are present within serpentinite in at least two locations in the A-6 quadrangle (Hawley and Clark, 1974). Neither occurrence is of significant size, and given the extsemely discontinuous and faulted nature of the serpentinite bodies. there is minuscule likelihood for a large chromite accumulation in the quadrangle. Although small amounts of disseminated or veialet pyrite bave been noted in some altered gabbroic rocks of the region, no magmatic sulfides have been identified, and no significant $\mathrm{Cu}-\mathrm{Ni}$ or platinum group metal anomalies have been found in the mafic intrusions (Hawley and Clark, 1974, Kurtak and others, 1992, Gage and others, 1998).

The vast bulk of known mineral resources in the Healy A-6 Quadrangle and vicinity (table 2) are spatially and temporally (table 1) associated with Cretaceous and Tertiary age intrusions. Although the various prospects and deposits possess similarities, those associated with Late Cretaceous intrusions are fundamentally different from those with Early Tertiary intrusions. The former contain significant Au resources and the latter significant Ag-Sn. Hawley and Clark (1974) drew similar conclusions, but regarded ald the intermediate-composition intusions as older, Au-related, and all the felsic-composition intrusions (including $\mathrm{Kg}$ types) as younger, Sn related. In many cases the two deposit types are difficult to distinguish. Arsenopyrite and pyrite are characteristic minerals of both types and anomalous concentrations of Sn. Bi. Te, and $\mathrm{Au}$ can be found in either type (Hawley and Clark, 1974; Warner and Dahlin, 1989; Kurtak. 1992; Gage and others, 1998). Empirically, however, the two types can be distinguished by their $\mathrm{Au}$ and $\mathrm{Ag}$ contents: the $\mathrm{Ag} / \mathrm{Au}$ ratios are invariably higher in most hand samples from the $\mathrm{Sn}-\mathrm{Ag}$ type than in hand samples from the Au-rype (fig. 2). When broken into these two types, based on Au and Ag contents, interpreted ${ }^{40} \mathrm{Ar} /{ }^{\beta 9} \mathrm{Ar}$ ages for mineralized and associated rocks mostly fall into two groups: $65-75$ Ma for the Au type and S2-58 Ma for the Sn-Ag rype (fig. 3). Thermal resetting of some older mineralization by Early Teriary dikes and intrusions appears to account for the majority of overlap between the two types.

Plutonic-related vein/breccia gold deposits in the region are exemplified by the Golden Zone deposit (Hawley and Clark, 1974). These deposits are spatially associated with reduced (low primary magnetite) granitic rocks ranging from intermediate to felsic compositions. The ores contain abundant arsenopyrite, pyrite, and commonly pymhotite, with lesser stibnite and/or antimony-sulfosalts, molybdenite, bismuthinite, Bi-Te-S minerals, and minor to trace scheelite, consistent with a reduced environment of formation (McCoy and others, 1998). Stannite is present in trace amounts. Gangue minerals include major quartz, very fine- to coarse-grained- white mica, calcite, and ferroan dolomite. Given this mineralogy, the geochemical expression is $\mathrm{Au}-\mathrm{As}-\mathrm{Bi}-\mathrm{Sb}-\mathrm{Te}(\mathrm{Zn}, \mathrm{Cu}, \mathrm{Ag}, \mathrm{B}, \mathrm{Sn}, \mathrm{Be})$.

Skams and sulfide replacement bodies (table 2) are present where carbonate-bearing rocks are present near mineralized Early Cretaceous plutons. Although they commonly contain abundant chalcopyrite, their higb Au/Ag ratios, abundant arsenopyrite, and high $\mathrm{Bi}$ contents indicate most are better classifjed as "gold skarns" than as "copper skarns" per se (Meinen, 1992; Newberty and others, 1998). Within the study area there are commonly some gold-bearing veins in the Au-rich skams, and some small amounts of skarn with the pluton-hosted 
s

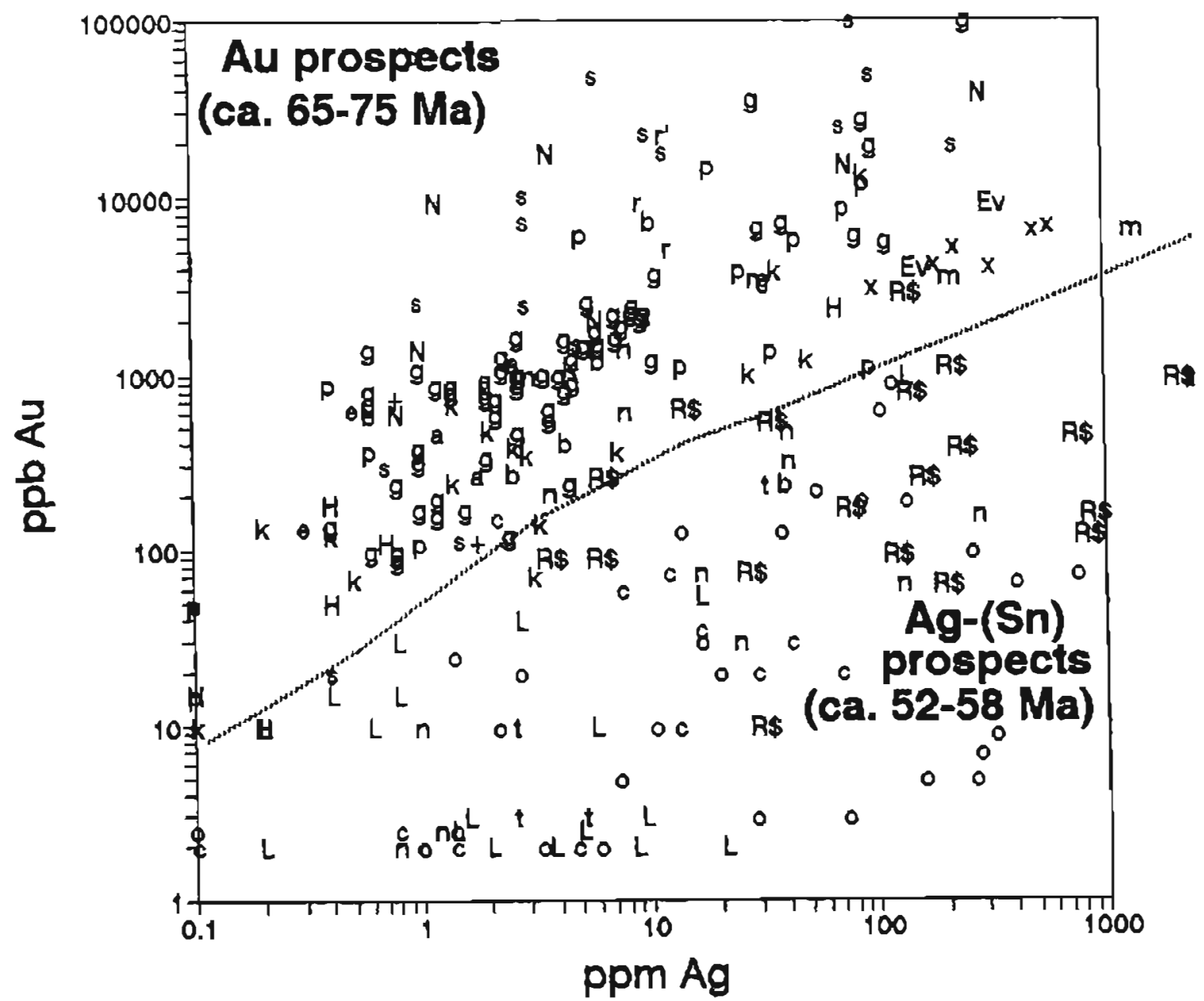

Fig. 2. Concentrations of silver vs. gold in mineralized samples from the Chulitna area, SW Healy 1:250,000 quadrangle. Prospect abbreviations: Golden Zone and nearby prospectsGolden Zone $=$ g, Riverside $=r$, East Vein $=$ Ev, Banner $(s k a m)=b$; Copper King $=k$; Silver King $=$ s; Long Creek $=x$; Honolulu $=H ;$ Nim $=\mathrm{N}$; Partin Creek $=p$; Eldridge $=e$; Silver Kitty $=\mathrm{a} ; \mathrm{McCaulie}$ glacier $=\mathrm{m}$; other late-Creteceous-type prospects $=+;$ Lookout $\mathrm{Mntn}=\mathrm{L}$; Obio Creek $=0$; Coal Creek $=\mathrm{c} ;$ Ready Cash $=\mathrm{R} \$$; nimbus $=\mathrm{n}$; and other early Tertiary-type prospects $=t$. Data from Hawley and Clark (1974), Warner and Dahlin (1989), Kurtak(1992), Newberry (1995), and Gage and others (1998). 
Table 2. Selected mineral deposits and prospects in the Healy A-6 quadrangle and vicinity

\section{Prospect Longitude Latitude Brief Description}

I. Mineralization associated with late Cretaceous intrusions

$\begin{array}{lccl}\text { Golden Zone } & -149.65 & 63.21 & \text { As-Au-Cu-Ag breccia pipe } \\ \text { Copper King } & -149.64 & 63.19 & \text { Cu-Au skarn (and porphyty Cu?) } \\ \text { Banner } & -149.62 & 63.23 & \text { As-Au-Ag skarn } \\ \text { Riverside } & -149.60 & 63.24 & \text { As-Au-Ag vein and sulfide replacements } \\ \text { Long Creek } & -149.66 & 63.18 & \text { As-Au-Ag veins and veinlets in hornfels } \\ \text { Kennicott } & -149.93 & 63.08 & \text { Disseminated sulfides in altered dikes????? } \\ \text { Eldridge Glacier } & -149.91 & 62.96 & \text { Disseminated sulfides in listwanite zone } \\ \text { Silver Kitty } & -149.78 & 63.16 & \text { Au-As intrusive stockwork } \\ \text { Partin Creek } & -149.95 & 63.07 & \text { Cu-Au veins, skarns, and carbonate replacements } \\ \text { McCallie Glacier Lode } & -149.32 & 63.26 & \text { As-Au-Ag veins and sulfide replacements } \\ \text { Honolulu } & -149.48 & 63.01 & \text { As-Ag-Au vein } \\ \text { Antimony } & -149.41 & 63.07 & \text { Sb-Au-Ag vein } \\ \text { Silver King } & -149.55 & 63.25 & \text { As-Au-Ag skans and veins } \\ \text { Silver Kitty } & -149.78 & 63.16 & \text { Disseminated As-Au-Ag in homfels near mafic stock } \\ \text { Nim } & -149.48 & 63.28 & \text { As-Au-Ag vein and sulfide replacements } \\ \text { B-S } & -149.32 & 63.26 & \text { As-Au mineralized homfels zone } \\ \text { II. Mineralization associated with early Tertiary intrusions } \\ \text { Coal Creek tin } & -149.86 & 62.99 & \text { Sn-Ag greisen } \\ \text { Ready Cash } & -149.85 & 63.14 & \text { Ag-Sn-Zn skarns, sulfide replacements, \& veins } \\ \text { Ohio Creek } & -149.92 & 63.18 & \text { Sn-Ag greisen and minor Zn-Ag skam } \\ \text { Nimbus } & -149.42 & 63.27 & \text { Low-F porphyry Mo (?) \& distal veins } \\ \text { Lookout Mountain } & -149.57 & 63.19 & \text { Distal (?) Sn-Ag toumaline stockwork }\end{array}$

veins/breccias, but the two deposit types appear to be largely mutually exclusive. Although high-carbonate rocks are the best host rocks, appreciable amounts of skarn are present in units with as little as 10 percent carbonate (for example, TrP?vs). The largest example is at Silver King (Hawley and Clark, 1974, Newberry and others, 1998) immediately north of the Healy A-6 Quadrangle.

These Au-rich skans contain, pyrite, magnetite, chalcopyrite, arsenopyrite \pm pyrrhotite as the dominant sulfides; small to trace amounts of bornite, molybdenite, scheelite, and $\mathrm{Bi}-\mathrm{Te}$ minerals are also present (Newberry, 1995). The most common gangue minerals are low-Fe garnet, high-Fe clinopyroxene, homblende, calcite, and quarz. The geochernical signarure for these deposits is: $\mathrm{Cu}-\mathrm{Ag}-\mathrm{Au}-\mathrm{Bi}-\mathrm{As}-\mathrm{Sb}-\mathrm{Te}-(\mathrm{Mo}-\mathrm{W}-\mathrm{U}-\mathrm{Be}-\mathrm{Co}-\mathrm{Ni})$.

Known Ag-rich prospects associated with Early Tertiary granites in the study region (table 2) are of two basic varieties: (1) vein/veinlet-dominated mineralization located outside of the parent granite body and (2) granite-hosted greisen deposits. The latter are large, bulk-tonnage deposits of near-economic potentlal (Kurtak, 1992); the former appear to be "distal" signals of deeper, and larger mineralized plutons. The best examples of polymetallic, Snbearing veins and sulfide replacements are present at the Ready Cash prospect (Hawley and Clark, 1974); lowergrade Sn-Ag mineralization associated with tourmaline breccias at Lookout Mountain probably has a similar origin. The ore mineralogy includes cassiterite and stannite, major arsenopyrite, sphalerite, galena, pyrite, and chalcopyrite, and minor wolframite, stibnite bismuthinite, and argentite. The geochemical expression is $\mathrm{Ag}-\mathrm{As}-\mathrm{Sn}-\mathrm{Zn}-\mathrm{Cu}-\mathrm{Pb}-$ Bi-W-Rb-B-Be-F-Li-Ga.

Tin greisen deposits are known in upper Ohio Creek in the A-6 quadrangle, and just south of the A-6 in upper Coal Creek. The Coal Creek deposit has been extensively diamond drilled and contains identified $\mathrm{Sn}-\mathrm{Ag}-\mathrm{Zn}$ resources. The Onio Creek prospect lies within Denali National Park and has not been drilled, but has been extensively sampled (Wamer and Dahlen, 1989). The ore minerals at both deposits include cassiterite and stannite, major arsenopyrite, sphalerite, pyrite, and chalcopyrite, and minor wolframite, galena, stibnite, bismuthinite, and argentite. Arsenopyrite and stannite-sphalerite geothernometry for the Coal Creek deposit indicate high $\left(>400^{\circ} \mathrm{C}\right)$ temperanures of formation (Parker, 1991). Quarz, fluorite, topaz, and Li-rich white mica are common accessories; 
tourmaline is variably present. Minor $\mathrm{Zn}-\mathrm{Pb}-\mathrm{Ag}$ skam is present in rare calcareous rocks near the Coal Creek prospects. The geochemical expression is $\mathrm{Ag}-\mathrm{Pb}-\mathrm{S}_{\mathrm{n}}-\mathrm{Zn}-\mathrm{Cu}-\mathrm{As}-\mathrm{Bi}-\mathrm{W}-\mathrm{Rb}-\mathrm{B}-\mathrm{Be}-\mathrm{F}-\mathrm{Li}-\mathrm{G}$.

The Copper King and Nimbus prospects (table 2) appear to be slight variations on the major deposit types present in the study area. Both are distinguished by containing porphyry-texrured felsic intrusive rocks with some stockwork quartz veining. At the Copper King prospect the majority of mineralization occurs in homfels and rare skard (developed from unit TrP?vs) as high-grade chalcopyrite-pynhotite-bomite masses. The high Cu and low As contents of this deposit (Hawley and Clark, 1977; Gage and others, 1998) also distinguish it from the otber Aubeariag skarns in the region. Based on its metallogeny and associations, it is better classified as a Au-rich copper skam (Newberry and others, 1998) and consequently the associated altered, Cu-bearing granite porphyry intrusion as a porphyry copper prospect. Variations in interpreted ${ }^{40} \mathrm{Ar} /{ }^{39} \mathrm{Ar}$ dates from this prospect (table 1, fig. 3) indicate thermal resetting by younger intrusions, and there may be multiple mineralization events present.

The Nimbus prospect, north of the Healy A-6 Quadrangle, lies within Denali National Park and has not been well studied. Swainbank and others (1977) describe it as a porphyry copper prospect, bur molybdenite is more obviously abundant than any copper minerals and Mo is present in more anomalous abundance than is Cu (Gage and others, 1998). Mineralization is confined to altered, felsic porphyry dikes, which locally constitute a dike swarm (Swainbank and others, 1977). The exposed rocks associated with mineralization are too weathered and altered for reliable chemical analyses or datisg and the nearby, less-altered dikes display ambiguous compositional characteristics. Some of these dikes possess compositions similar to demonstrably Cretaceous granites, others to demonstrably Early Tertiary granites of the region. Dating of $\mathrm{K}$-feldspar from a less-altered felsic dike yielded a plateau age of $61 \mathrm{Ma}$-intermediate in age between the two major types. Most likely this intermediate age indicates the presence of botb Late Cretaceous and Early Tertiary igneous activity. Due to the elevated Mo and Ag concentrations of the known mineralization (Gage and others, 1998), we categorize the bulk of hydrothermal activity as distally (?) related to a porphyry Mo system.

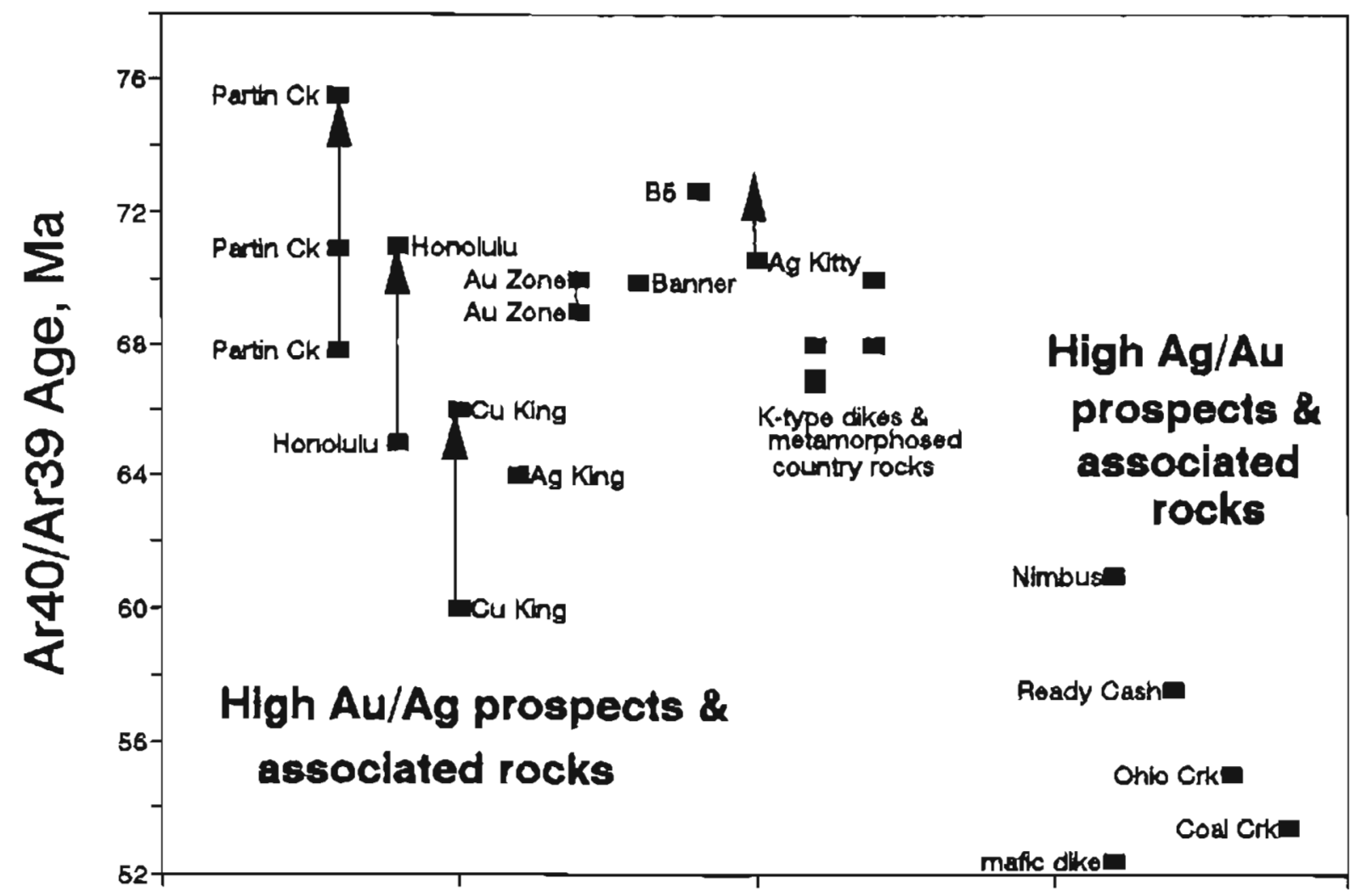

Figure 3. Interpreted ${ }^{40} \mathrm{Ar} /{ }^{\beta 9} \mathrm{Ar}$ ages for mineralized and related rocks in the Chulitns region. An upward-pointing arrow indicates that the sample's Ar spectrum shows evidence for thermal reset and thus the "age" is a minimum. Note the clear age separation between those prospects (fig. 2) characterized by lower Ag/Au ratios (approximately 65-75 Ma) and those characterized by high Ag/Au ratios. Except for Nimbus, a weakly mineralized porphyry Mo prospect of uncertain age, the high $\mathrm{Ag} / \mathrm{Au}$ deposits all contain appreciable $\mathrm{Sn}$. Data from this study. 


\title{
DESCRIPTION OF MAP UNITS
}

\section{UNCONSOLIDATED DEPOSITS}

\author{
Alluvial Deposits
}

Qa UNDIFFERENTIATED STREAM ALLUVIUM - Elongate deposits of moderately to well sorted, well stratified, fluvial pebble-cobble gravel. sand, and silt, with few to numerous boulders, deposited in active stream channeis, floodplains, and associated low terraces. Deposit is medium to thick bedded, locally crossbedded, and shows fining-upward cycles. Cobbles generally rounded and reach a maximum diameter of $1 \mathrm{~m}$. Extensive willow-alder thickets grow on many $\mathrm{Q}$ a deposits in mature valley fills. Surface smooth except for local low scarps.

Qac ABANDONED-CHANNEL DEPOSITS - Elongate variable deposits in channels of former meltwater streams not related to modem stream regimens and subsequent underfit strearns. Composition ranges from slightly washed drift with thin, local surface lags of cobbles and boulders to well-sorted, clean pebble-cobble gravel and gravelly medium to coarse sand with rare to numerous boulders; thin to thick bedded, locally crossbedded. Surface smooth with local low scarps and bogs.

Qaf ALLUVIAL FAN DEPOSITS - Fan-shaped, heterogeneous mixtures of poorly to moderately sorted, partially stratified, channelized gravel with some sand and sitt and scattered to numerous, subangular to rounded boulders, especially in proximal areas. Clasts locally derived. May include torrential fluvial deposits and debris-flow deposits. Thick 10 thin bedded. Generally localized at intersection between first and second order (uibutary and trunk) streams. Surface smooth except for numerous shaliow, interconnected channels.

Qat TERRACE ALLUVIUM - Elongate deposits of well-sorted, well-rounded to subrounded pebble-cobble gravel and sand with trace to some silt and rare to numerous boulders up to $50 \mathrm{~cm}$ diameter comprising stream terraces bordering modern floodplains and clearly related to modern drainage; includes strath terraces. Surface smooth except for local low scarps.

Qfp FLOODPLAIN ALLUVIUM - Elongate deposits of moderately to well sorted, well stratified, fluvial gravel, sand, and silt with few to numerous boulders forming modern floodplains and associated low terraces. Typically mantled by thin layer of silty overbank deposits. Generally finer grained than similar deposits in Qa unit because of deposition during flood-stage events. May locally include Wisconsin to Holocene terrace alluvium. Lower surfaces may be flooded during periods of maximum stream discharge. Highly variable thickness difficult to estimate due to poor exposure. Surface smooth to hummocky with local low scarps and bogs.

\section{Colluvia! Deposits}

Qc UNDIFFERENTIATED COLLUVIUM - Irregular, heterogeneous blankets, aprons, and fans of angular to subrounded rock fragments, gravel, sand, and silt that are left on slopes, slope bases, or high-level surfaces by residual weathering and complex mass-movement processes, including rolling, sliding, flowing, gelifluction, and frost creep. May include greatly modified drift of older glaciations. Locally washed by meltwater and slope runoff. Medium to thick bedded; thickness highly variable. Surface smooth, lobed or terraced and generally reflects configuration of underlying bedrock surface.

QCl LANDSLIDE DEPOSITS - Oval- to tongue-shaped heterogeneous mixcures of fractured bedrock and pebble-cobble gravel with trace to some sand and silt deposited by near-surface to deep creep, flowing, and sliding due to instability of failed bedrock and unconsolidated surficial deposits. May be block-supported, especially in the upper parts. Surface ranges from slightly irregular and broken by arcuate ground cracks and low ridges, to hummocky and covered with jumbled, openwork rubble with individual blocks up to $15 \mathrm{~m}$ diameter. 
Qct TALUS AND RUBBLE DEPOSITS - I Iregular cones, drapes, and sheets of coarse ( $\mathrm{l} \mathrm{m}$ diameter and larger blocks are common), heterogeneous, angular rock fragments and rubble with minor silt, sand, and gravel deposited more or less in place on steep upper slopes and at the mouths of steep bedrock couloirs by block weathering, frost riving, snow avalanches, free fall, tumbling, rolling, and sliding. Deposits are widely subjected to secondary reworking by cryoturbation, including frost heave and frost jacking of rock fragments. Surface steep, irregular, generally unvegetated, covered with numerous angular rock fragments, and characterized by openwork nibble mounds many meters thick.

Qrg ROCK-GLACIER DEPOSITS - Tongue- and fan-shaped heterogeneous mixures of angular to subangular blocks of local bedrock and ice with trace to some gravel, sand, and silt at depth that accumulates on floors and lower walls of cirques by flow of rock glaciers derived from shrinking of former glaciers (ice cored) or from deposition and cementation of precipitation-derived ground ice (ice cemented). Perennially frozen where active. Probably generally clast-suppored. Surface furrowed, concentrically ridged, pitted, or hummocky and covered with angular to subangular blocks up to 2 in diameter; generally unvegetated, but locally overgrown with moss, lichen, and some grass on inactive and less active rock glaciers.

\section{Paludal Deposits}

Qs SWAMP DEPOSITS - Elongate to blanket deposits of complexly bedded peat, organic silt, and organic sand accumulated as surface deposits in local basins and in former stream channels. Saturated and locally frozen, locally ice rich. Thickness highly variable. Surface smooth, hummocky, or pitted. May have standing water.

\section{Glacial Deposits}

Qao OUTWASH ALLUVIUM - Elongate to fan-shaped heterogeneous mixture of washed, rounded to subrounded pebble-cobble gravel with some sand and silt and scattered to numerous subangular to rounded boulders deposited by meltwater streams draining margins of former glaciers. Thin to thick bedded, locally crossbedded. Surface generally smooth and gently sloping, except for local low scarps.

Q12 TTLL OF LATEST HOLOCENE AGE - Heterogeneous mounds and ridges of pebble-cobble gravel, sand, silh, and clay in varying proportions deposited at or near the margins of modern glacial ice or where glacial ice has existed until very recently; contains rare to numerous large ( $2 \mathrm{~m}$ diameter and greater) boulders. May be ice cored. Surface hummocky with numerous scattered boulders and generally retains primary morainal morphology; little or no vegetative cover or soil developmeat.

Qt1 TILL OF EARLY TO MIDDLE HOLOCENE AGE - Heterogeneous mounds and ridges of pebble-cobble gravel, sand, silt, and clay in varying proportions deposited directly from glacial ice; contains rare to numerous large ( $2 \mathrm{~m}$ diameter and greater) boulders. Surface hummocky with numerous scattered boulders and generally retains primary morainal morphology; nominal soil development with well-established vegetation consisting primarily of lichen, moss, and herbs.

Qd DRIFT OF LATE WISCONSIN AGE - Heterogeneous blanket of pebble-cobble gravel, sand, silt, and clay in varying proportions deposited by glaciers; contains rare to numerous large ( $2 \mathrm{~m}$ diameter and greater) boulders deposited directly from glacial ice. Sorting, bedding, and clast roundness highly variable, depending on degree of water reworking. Deposit locally includes or is gradational with outwash. Clay-rich diamictons may form high, steep slopes where incised by streams and are subject to earthflows when saturated. Locally forms steep-sided, sinuous ridges (eskers) up to $12 \mathrm{~m}$ high and $4-5 \mathrm{~m}$ wide at the crest. Thickness ranges from a thin and patchy veneer over ice-scoured bedrock to more than $25 \mathrm{~m}$ thick. Typically overlain by up to $1 \mathrm{~m}$ windblown silt. Surface smooth to highly irregular with local bogs and ponds. Based on geomorphological relationships, deposit is probably correlative with deposits of the last part of the Riley Creek glaciation in the Nenana River valley on the north side of the Alaska Range (Wahrbaftig, 1958), and deposits of the Elmendorf stade of the Naptowne glaciation in the Cook Inlet region (Reger and Pinney, 
1996). The latter part of the Riley Creek glaciation has been dated to approximately $9,500-12,800$ yr B.P. (Ten Brink, 1983), and the Elrnendorf stade dates to approximately 9,500-14,000 yr B.P. (Reger and Pinney, 1996).

\title{
Complex Deposits
}

Qcf COLLUVIAL-ALLUVLAL VALLEY FILL, FAN, AND APRON DEPOSITS - Elongate, apron- and fanshaped, heterogeneous mixtures of poorly 10 moderately sorted angular rock fragments with trace to some gravel, sand, and silt of alluvial and colluvial origin deposited at the bases of steep slopes bordering modern stream valley courses and at the mouths of bedrock couloirs and gullies. Deposited primarily by debris flows and brief, intense (torrential) summer stream flows. May include snow-avalanche deposits. Commonly forms alternating stratified and unstratified zones and lenses in gullies and steep tributary valleys with intermittent or eptemeral streans. Locally wasbed by meltwater and slope runoff. Youthful alluvial-colluvial fan deposits are actively being formed or modified when seasonal snowpack is melting. Surface steep to gently sloping, with local low scarps.

\section{BEDROCK UNITS}

\section{SEDIMENTARY AND VOLCANIC ROCKS}

\author{
Tertiary sedimentary rocks
}

Tes Gravel and sand (Miocene? to Paleocene?) - Orange to buff-colored, well-sorted, clast-supported, sandy pebble-cobble gravel and sand. Measured thicknesses of this unit range from 6 to $45 \mathrm{~m}$. The deposit shows varying degrees of orange and purple-black (manganese oxide) discoloration and weathers to light buff or grayish brown. While typically poorly to moderately consolidated, the unit is locally indurated enough to approach a true conglomerate. The deposit forms bare, vear-vertical cliffs where incised by streams and is prone to gullying. Clasts are subrounded to very well rounded, and median clast size is approximately $5 \mathrm{~cm}$ diameter. The largest cobbles are generally not more than about $15-20 \mathrm{~cm}$ diameter, although can locally exceed $40 \mathrm{~cm}$ diameter. Clast lithology is typical of an Alaska Range source area, including chert, argillite, graywacke, volcanic rocks, felsic to intermediate intrusive rocks, and the distinctive conglomerate from the Cantwell Group. Many of the granitic to dioritic clasts are rotten, especially the more mafic ones. The deposit is predominantly massive to thick-bedded, and has an overall horizontal fabric. It is locally very well bedded with crosscutting channels and crossbedding, especially in sand beds and in some pebble beds. Local channeling is most apparent in sandy units. Sand beds typically constitute no more than 2-5 percent of the section, but are locally much more abundant. Sands occur mostly as broad lenses with an average thickness between $10-20 \mathrm{~cm}$ and a maximum measured thickness of $80 \mathrm{~cm}$. Silt bodies are very rare, occurring as lenses up to $35 \mathrm{~cm}$ thick that may locally exhibit soft-sediment deformation structures due to loading. Pollen samples collected from the rare silt beds proved to be too oxidized for analysis. The upper contact of the deposit is erosional, manifesting as a slightly irregular surface that appears to dip to the south. This deposit is fluvial in origin, and was laid down by a very active sediment-laden stream system that probably developed in association with the uplift of the Alaska Range during Tertiary time. This deposit is probably carrelative with the Nenana Gravel on the north side of the Alaska Range. This unit is preserved in the down-dropped, fault-bounded block, or graben in Broad Pass in the southeastern portion of the map, where it can be observed in exposures up to $100 \mathrm{~m}$ thick.

\section{Cretaceous to Jurassic rocks}

KAHILTNA ASSEMBLAGE (Late Jurassic and Early Cretaceous; Reed and Nelson, 1980; Csejtey and others, 1978, 1982, 1992; Nokleberg and others, 1994) - The Kahilma assemblage is found in the northwest and southeast comers of the map area and may underlie the intervening older rocks. It consists of a monotonous, highly deformed flysch succession of fine-grained lithic sandstone, argillite, highly siliceous argillite, and rare conglomerate and limestone. This predominantly turbidite assemblage is some several thousand meters thick, and bedding and cleavage dip typically to the southeast, and fold vergence is 
predominantly to the northwest. Regionally the Kahitma assemblage underlies a large area of south-central Alaska, and locally includes large thrust sheets or nappes of Upper Triassic pillow basalt (Jones and others, 1980). Early Cretaceous fossils (belemnite guards and Inoceramus prisms) similar to those reported to the south by Jones and others (3980) were recovered from the northwest map area (localities 2,3,4 in Blodgett and Clautice, 1999). Regionally, Jones and others (1980) report Inoceramus, belemnites, and Buchia sublaevis of Cretaceous age, and radiolarians of Upper Jurassic age. Below we subdivide the Kahiltna assemblage into three mappable lithologic units: (1) Argillite and sandstone, (2) Sandstone and argillite and (3) Conglomerate.

KJas Agillite and Sandstone unit - Dark-gray to very dark gray and black, argillite (locally phyllitic) and dark gray sandstone. Rocks weather brown, orange-brown, and reddish-orange. Argillite is greater than 50 percent of this unit and locally sandstone may be as little as 10 percent of the unit. Cleavage is prominent in this unit and is commoniy the dominant outcrop characteristic. Cleavage is commonly parallel to bedding, however, where it is not the relationsbip generally indicates folding- or overturning with a northwest vergence. North of the East Fork Chulitna River this unit is locally cross-cut by mafic and felsic dikes. White quartz veining, locally with sulfides, and locally as crystal filled vugs and fractures, is up $1030 \mathrm{~cm}$ thick and locally up to $2 \mathrm{~m}$ thick.

KJsa Sandstone and argillite unit - Sandstone with much lesser argillite. Predominantly dark-gray, poorly sorted, sub-angular, fine- 10 medium grained lithic sandstone, thythmically layered with darkgray, locally carbonaceous argillite. Sandstone weathers dark gray, medium gray, and locally light gray or orange brown. Sandstone is about 80 percent and argillite about 20 percent of this unit. Sandstone beds are laterally continuous, have sharp non-erosive bases, are generally thin-bedded with lesser medium-bedded, and rare amalgamated beds to $50 \mathrm{~cm}$ thick. Beds are intenaily massive or graded, with Bouma intervals Tame, Tbde, and Tde common. The depositional environment for this unit is a middle submarine fan (Muri and Ricci Lucci, 1978) on the basis of sedimentary structures and beding characteristics. Sandstone bocally contains carbonate along with the ubiquitous clay matrix, and framework clast estimates are 70 percent quartz, 20 percent black argillite (low-grade metamorphic rock) including ripup clasts, 10 percent gray chert (with rare white tripolitic cher), and minor white mica. Cleavage is locally the dominant structural feature. Hornfelsed adjacent to pluton and dikes locally forming andalusite-spotted hornfels. In the headwaters of Antimony Creek cross-cut by gabbro dike. Includes rare conglomerate that is shown as rap unit where thicker than $1 \mathrm{~m}$.

KJc Conglomerate - Medium-gray, poorly sorted, matrix-supported, polymictic pebble to cobble conglomerate. Matrix is fine to medium-grained sandstone and constitutes about 15 to 20 percent of the rock. Clast estimates are 70 percent quarz, 20 percent black argillite (low-grade metamorphic rock), and 10 percent gray chert (with rare white tripolitic chert).

KJs Caicareous sandstone and argillite, with coquinoid limestone unit - (Early Jurassic to Early Cretaceous) Predominantly medium gray, poorly and very poorly sorted, sub-angular with lesser sub-rounded, fine to medium grained, tan to light gray, orange-brown weathering calcareous, lithic sandstone interlayered with dark gray argillite, rare coquina limestone to $2 \mathrm{~m}$ thick composed of comminuted Buchia sublaevis shells (Valanginian, Lower Cretaceous age, localities 11, 13, 38, 39, 93 in Blodgett and Clautice, 1999). Rare thinbedded, quartz grain-bearing carbonate (rubble only). This map unit is found uncomformably overlying older units within the fault-bounded Chulitna block. It is most prevalent in the northeast map area overlying and folded with unit TRJb, but we have also included calcareous sandstone and thin-bedded limestone to the south within this unit based on a Buchia occurence (locality 93). Lower Jurassic calcareous sandstone with thin beds of phosphatic, sandy, ammonite-bearing limestone are also tentatively included within this unit (sandy portions of Jones and others, 1980 "Jac" unit, which hosts Sinemurian, Early Jurassic age ammonites, localities 104,105,132, 137, 147, 152 in Blodget and Clautice, 1999).

The relationship of this unit to Kahiltna rocks of similar age is unclear. It is possible that it represents a nearshore facies of the deeper-water Kahilma assemblage. Calcareous sandstone is the distinguishing litbology of this unit and comprises less than 25 percent, whereas the unremarkable argillite constitutes more than 70 
percent of this unit. Sandstone bedding is thin. parallel, laterally continuous, and conformable with coquina beds; where the bounding clastic rocks are very-fine-grained red- to maroon-weathering sandstone and siltstone. The distinctive coquinoid limestone weathers maroon to dark reddish-brown and is composed of broken shells, which locally range $10+\mathrm{cm}$ in diameter. Petrographic analysis indicate sandstone framework grain averages are: 60 percent chert. 10-15 percent polycrystalline quartz, 10-20 monocrystalline quartz, 10 percent to minor sedimentary rock fragments. 5 percent to minor plagioclase, minor to trace volcanic rock fragments, and other trace minerals include white mica, homblende, and glaconite. Aqua-blue chert clasts are rare but distinctive. Sandstone matrix is iron-rich carbonate and calcite, with only minor clay component. Matrix ranges from 5-15 percent of the rock, with an average of less than 10 percent. Porosity in sandstone is very minor due to secondary carbonate cement. Structurally these rocks are isoclinally folded, and the resulting cleavage is the dominan fabric in the hinge regions and less dominant distal from the hinges. The closely spaced cleavage is especially prominent in the argillaceous lithologies where it locally forms pencil cleavage. Sandstone petrography indicates a recycled orogenic provenance. Furthermore, the provenance is more characteristic of the collisional recycled orogenic provenance than the foreland uplift recycled orogenic provenance due to: 1) more abundant plagioclase relative to lithic rock fragments and, 2) more polycrystalline quartz relative to sedimentary rock fragments. The coquinoid limestone layers within this map unit are rare but significant, and similar to coquinoids of Valanginian age known in the Kandik basin of east-central Alaska and Yukon Territory. Additionally, they are similar to coquinoids on the Alaska North Slope, which crop out along the foothills of the Brooks Range from the Delong Mountains in the west to the Shaviovik front east of the Dalton Highway. All of these deposits are within a siliciclastic stratigraphic package and represent shelfal deposition. in water depths of less than about $125 \mathrm{~m}$. All of these thin $(0.2-3,0$ $\mathrm{m}$ ) carbonate horizons may represent a local sediment flushing, wintowing and shell disagregation (with no substantial transport) due to episodic high-energy storms, or this stratigraphy records destructive reorganization of pelecypods which included some down-slope transport.

Jac Argillite, cherty argillite, and minor cherty tuff and basaitic tuff - Mostly argillite exhibiting complex deformational fabrics and sub-greenschist metamorphic mineralogy. This unit is characterized by argillite, cherty argillite, with minor cherty tuff and basaltic tuff. Light gray to black rhythmically bedded chert predominates. In places this unit is highly sheared and phyllitic. Radiolarians from this unit are of Late Jurassic age (localities 5, 106, 107, 111, 112 in Blodgett and Clautice, 1999).

\section{Triassic to Permian(?) Rocks}

Trlb Basalt, basaltic tuff and limestone - Predominantly massive (occasionally pillowed) basalt and basaltic tuff 50-100 m thick interlayered with fine-grained gray limestone. Near some contacts with basalt the limestone is coarsely ecrystallized and sheared, other contacts display fossiliferous limestone immediately adjacent to basalt. Major to minor chlorite-albite-carbonate-hematite alteration in the basalt is ubiquitous. The basalt is subalkaline (fig. 4a) and tholeitic, characterized by "within-plate" trace element abundances (fig. 5a), strongly magnetic, and dark-green weathering. Trace and major element concentrations in the basaltic rocks (figs. 4-6) are indistinguishable from those of the late Triassic Nikolai greenstone flood basalts. The limestones contain colonial scleractinian corats, megalodontid bivalves, and

Figure 4 (facing page). Rock type classification of Healy A-6 and vicinity igneous and meta-igneous rocks employing the $\mathrm{Zr} / \mathrm{Ti}$ vs. $\mathrm{SiO}_{2}$ discrimination diagram of Winchester and Floyd (1977). Symbol modifiers: " mineralogy indicates chemical alteration; " = highly altered; $g=$ gabbro; $t=$ tuff; $?=$ rock type/age assignment based on rock composition-field evidence is ambiguous. Figure 4A: Paleozoic and Triassic metaigneous rocks: $D=D v ; r=$ TrPvs ("redbeds"); ut = uPat; $N=$ igneous rocks from units Trlb and Trb; $n=$ late Triassic Nikolai basalt from the Wrangell Mountains; bp $=$ tuff in Paleozoic rocks of Broad Pass (Pzst). Figure 4B: late Cretaceous and early Tertiary intrusive rocks: $k=$ Cretaceous mafic-intermediate composition rock; $G Z$ = plutonic rock from the Golden Zone deposit; $\mathrm{k}^{*}=$ Cretaceous felsic composition rock; $\mathrm{T}=$ Tertiary mafic dike; $\mathrm{t}=$ Tertiary felsic intrusion. Data from Hawley and Clark (1974), Balen (1990), Newberry and Solie (1995), and Gage and others (1998). 

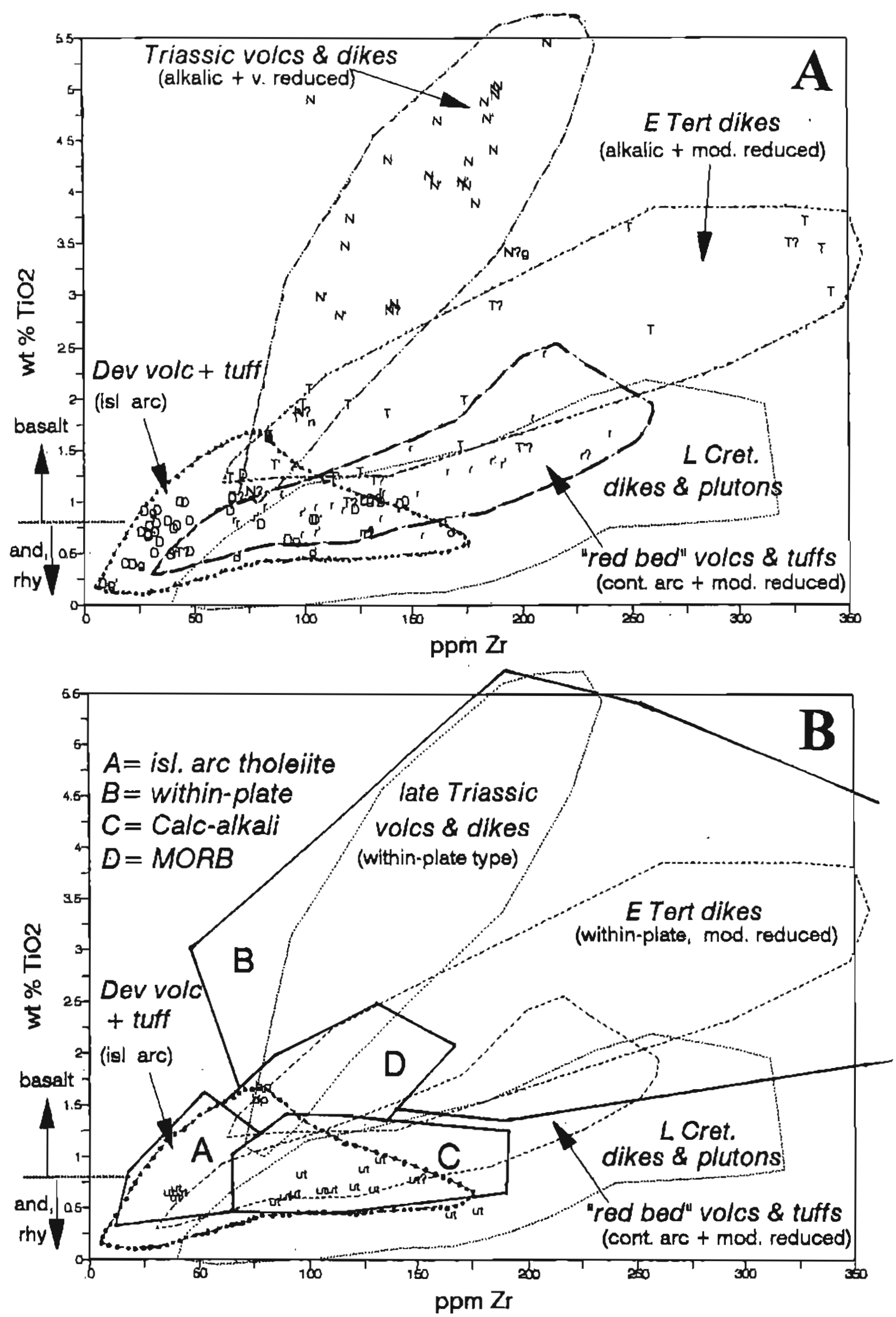


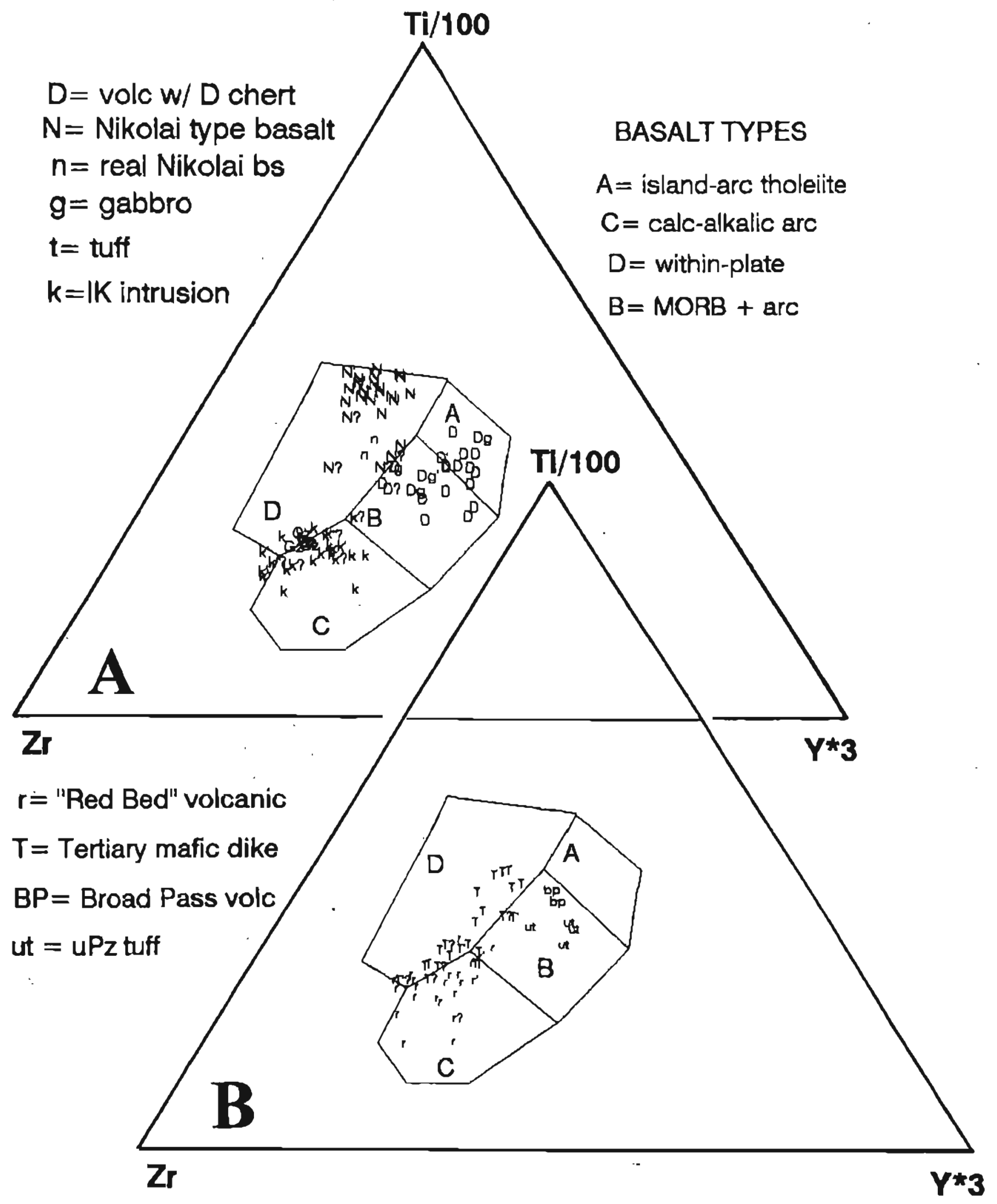

Fig. 5. Tectonic classification of Healy A-6 and vicinity basaltic-composition igneous and meta-igneous rocks employing the Ti-Zr-Y discrimination diagram of Pearce and Cann (1973). 5A: mafic rock compositions from units Trlb, Trb, Dv, and $\mathrm{Km}$. 5B: mafic rock compositions from units Tb, uPzh, uPzst, and TrPvs. Symbols and data references as in Fig. 4. 


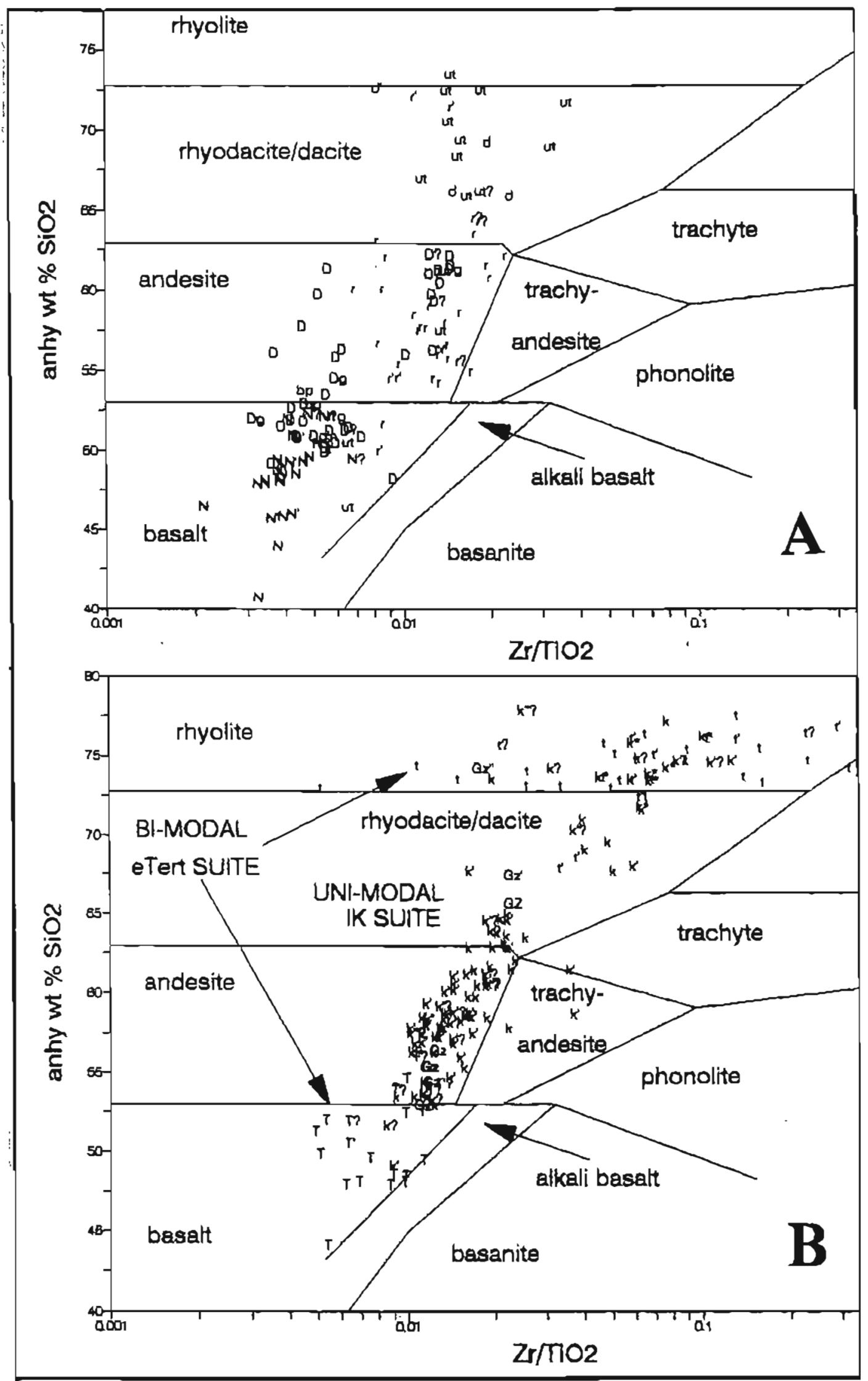


Figure 6 (previous page). Weight \% TiO2 vs. ppm $\mathrm{Zr}$ for all igneous and meta-igneous rocks of the Healy A-6 vicinity, showing contrasting immobile element characteristics of the various units. Fig. 6A: Data from units Dv, TrPvs, Trlb, Trb, and Tb. Fig. 6B: fields (in dashed and dotted lines) for all the various igneous rock units of the Chulitna area, fields (in solid lines) for matic-intermediate igneous rocks of various tectonic settings (modified from Pearce and Carn, 1977), and data for tuffaceous rocks of units uPzt and uPzst. Note the clearly distinguishabje compositional fields for the within-plate upper Triassic and early Tertiary mafic rocks and the overlapping, but distinguishable fields for the calc-alkaline (arc-related) igneous rocks of the "red bed" unir and of the late Cretaceous intrusions. Igneous rocks of unit DV appears to evolve from island arc-type tholeite to calc-alkalic volcanics. Combined with similarities in paleontological ages for nearby units, the near-perfect overlap in inumobile element compositions between unit Dv and unit uPzt ("ut") indicates that these are likely correlative units.

the brachiopod Spondylospira lewesensis (Lees), and the age is probably Norian. Trlb appears to depositionally overly unit Trs: the contact is mapped at the first basalt flow adjacent to Trs. Preliminary paleomagnetic investigations (Stone and others, 1999) indicate a paleolatitude of formation at $5^{\circ}$, consistentwith the paleontologic record and the paleolatitude of the Nikolai flood basalt of southerm Alaska. But it is not known whether these rocks were normally or reversely magnetized, therefore it is not known whether this represents a paleolatitude north or south of the equator. Given that the basalts are compositionally indistinguishable from Nikolai greenstone, that fossil ages are compatible with those of the assocjated Chitistone limestone, and that preliminary paleomagnetic data suggests a similar latitude of formation, we infer that Trlb constirutes a varient of the Chitistone-Nikolai units of Southern Alaska. We consequently infer that Trlb belongs to the Wrangellia terrane, and consequently that it-and by inference the associated rocks - are a par of the Wrangellia terrane as suggested by Jones and others (1980).

TRb Basaltic dikes and sills - Fine grained, equigranular to porphyritic, strongly magnetic, mafic intrusive rocks, similar in appearance and indistinguishable in composition (fjgs. 4-6) from the basalt of unit Trlb. Has been noted most commonly as dikes and sills, $1-3 \mathrm{~m}$ wide, in units TrPvs and Trs, but also occurs as plugs (?) or composite dikes in TrPvs. ${ }^{10} \mathrm{Ar} / 39 \mathrm{Ar}$ dating indicates a minimum age of $177 \mathrm{Ma}$ (table 1). These relations indicate that unit Trlb is younger than Trs and TrPvs, contradicting the inferred stratigraphic relations of Jones and others (1980).

uTrl Limestone - Thin- to thick-bedded limestone with subordinate shale and calcareous siltstone; limestones well bedded, unit at least $300 \mathrm{~m}$ where well exposed in the upper reaches of Long Creek. Carbonate lithologies include mudstone, wackestone, packstone and even rudstone (rare); locally with silty and argillaceous admixtures. A prominent interval composed of in situ colonial scleractinian thicket reefs crops out in the upper canyon of Long Creek. Unit contains a rich Norian-age fauna of brachiopods, scleractinian corals, bivalves, and less common gastropods.

TRs Brown sandstone and argillite - Thick-bedded, yellow-brown weathering sandstone and argillite with minor calcareous sandstone and sandy limestone. Overlies in grational contact red sandstones and conglomerates of the upper, sediment-dominant portion of unit TRPvs, the contact is taken at the first appearance of brown-weathering, calcareous sandstone. Underlies the limestone-basalt unit, TRlb. Abundantly fossiliferous horizons yield large $(4 \mathrm{~cm}$ diameter) heterastridium, snails and bivalves (localities 150, 151 Blodgett and Clautice, 1999).

TRP(?)vs Red-colored tuff, andesite, basalt, graywacke, conglomerate - An extremely heterolitbic unit with perhaps $2 / 3$ volcanic or volcaniclastic rocks and $1 / 3$ non-volcanic rocks. Volcanic dominant in the lower portions of the unit (commonly exposed in the northeast part of Healy A-6) and grades into sedimentdominant in the upper portions (common in southwest Healy A-6). White, quartz-pebble, matrixsupported conglomerate is typical of coarser portions of the upper sedimentary section while angular, clast-supported volcaniclastics are prevalent in the volcanic-dominant lower portion. 
The lower portions are red-colored lithic tuffs, red chert-bearing conglomerate, greywacke, and calcareous sedimentary rocks with minor andesitic flows. Volcanic members are predominantly calcalkalic andesice tuffs and tuff breccias, but compositions range from calc-alkaline basalt to dacite. Generally non-magnetic due to oxidation of primary $\mathrm{Fe}$-Ti oxides to hematite, presumably a result of sub-aerial deposition. Where present near Cretaceous intrusions, unit is hornfelsed to a green, hard rock with remnant ruffaceous textures. Unconformably underlain by limestone containing fossils with ages ranging from Pennsylvanian(?) to Permian. The unit is locally cut by dikes and sills of tholeiitic basalt composition indistinguishable from unit Trlb, which further implies a pre-upper Triassic age. The compositions, ages and lithologies of the lower portion are similar to the Pennsylvanian-Permian volcanic rocks of the Skolai arc of south-central Alaska.

Equivalent in part to the "red beds" unit of the northeastem belt of Jones and others (1980, p. A6-A7). This unit directly overlies Penmian limestone; where the limestone is absent it overlies PenrisylvanianPermian mudstone and greywacke. The basal contact of the unit is a red chert-pebble conglomerate; the chert contains upper Devonian radiolaria and is apparently derived from unit Dc. Consequently, we infer that the lower contact of unit TrP?vs represents a major unconformity. The common red color of this unit is due to its andesitic-basaltic bulk composition and to syngenetic or diagenetic oxidation. Rarely, if ever, is this unit a hematitic sandstone, or a "redbed" in the commonly accepted use of the term. Total thickness unknown, but at least $300 \mathrm{~m}$ thick and probably quite variable in thickness.

The upper portion of unit TrP(?)vs consists principally of red- to maroon-weathering, calcareous siliciclastic rocks (especially graywacke, siltstone, and conglomerate) with minor andesitic composition sills(?) or flows(?). The graywackes are commonly coarse-grained, primarily red weathering, but less commonly light-green weathering, matrix-supported, clearly sedimentary rocks. Gray wearhering, sandy conglomerate, with white, well-rounded, matrix-supported quarz cobbles is a distinctive lithology of this part of the unit. With a decrease in hematite content and an increase in sandstone maturity, calcareous cement and thin limestone layers, this unit grades into unit Trs. In some cases there is a thick, apparently upper Triassic, limestone bed near the top of or above unit TrP(?)vs.

ITR1 Lower Triassic limestone - Thin-bedded, light gray, light brown weathering mudstone and packstone. Recognized within smalt, high-angle fault slivers in two localities in the northeastern map area. Both exposures are $<4 m$ in strike length and $1-2 \mathrm{~m}$ thick. In the eastem-most exposure, Nichols and Silberling (1979) recognized 13 identifjable species of ammonite fossils in a single 10-cm thick bed. The collection is significant because the closest rocks of similar age (Smithian) and equatorial paleolatitude $\left(10^{\circ}\right)$ are found in northem Washington. At the time of our visit this exposure was in a cat trail near the Golden Zone mill and all fossils had been "mined." The second locality, about $2 \mathrm{~km}$ to the west, is exposed as orange-brown weathered, silicified packstone to wackestone with poorly-preserved fossil material in rubbly outcrop over a few square meters above a trail along an old flume. A siliceous encrinoidal limestone (locality 25, Blodgett and Clautice, 1999) about 30m downslope and along the flume trail may also be from this unit, but local faulting suggests that it is more likely a sliver of unit Pl. Surrounding rocks are red-colored, coarse-grained volcaniclastics frora unit TRP?vs.

\section{Permian to Devonian Rocks}

Pl Limestone (Permian) - Approximately $100 \mathrm{~m}$ thick succession of limestone subdivided into distinct lower and upper units. Lower unit composed of medium to thick bedded limestone, light-gray to orangeyellow weathering and locally highly silicified. Lithologies include mudstone, packstone and grainstone, frequently with argillaceous partings. Horridonid are common near base of lower member. Upper unit composed primarily of medium to thick bedded, light to medium gray weathering limestone. Carbonate lithology is predominantly encrinoidal packstone to grainstone. The limestone contains abundant megafauna of "Arctic Permian" rype consisting of brachiopods, bryozoans, pelmatozoan debris, solitary rugose corals, ostracods, and trilobites. Conformably and gradationally overlies a succession of Permian- 
age argillite and graywacke and is unconformably overlain by a thick "red bed" volcaniclastic sequence (unit TRP?vs).

PPs Permian mudstone and graywacke - Unit is at least $200 \mathrm{~m}$ thick and composed of thinly-bedded mudstone and graywacke. Lower part of unit dominated by gray-green graywacke turbidites that weather to yellow-brown, composed of lithic sandstones, 3-60 cm thick, interbedded with thin intervals of mudstone. Fossils not observed in the lower part of the unit. Thin-bedded, medium to dark gray and yellow-brown mudstone and siltstone predominate in the upper part of this unit, with trace fossils of the ichnogenera Chondrites and Scalarituba, and relatively scarce small brachiopods, bivalves, and bryozoans near the top of the succession. Unit conformably and gradationally underlies Permian limestone unit (PI). Unit well exposed along north-south trending ridge in SE1/4,NE1/4 Sec. 17, T20S, RIIW, and along hillside both above and below ditch in NW1/4NEl/4 Sec. 4, T20S, RIIW.

Dv Andesitic tuff and flows - Predominantly green-weathering, pyroxene andesite tuff and flows, but compositions range from island-arc tholeiitic basalt (locally pillowed) to dacitic tuff (figs. 4, 5). Previously mapped as "Tertiary gabbro breccia" in the Golden Zone mine area (Hawley and Clark, 1977) and as part of a Devonian ophiolite (Jones and others, 1980). The lower contact is interlayered with Devonian red chert. The upper contact is difficult to discern, appears to be somewhat gradational and may represent either an erosional unconformity or interfingering with overlying sedimentary rocks of unit PPs. Because the unit itself is not fossiliferous, the age is uncertain, but is most likely upper Devonian to Pennsylvanian in age. Lower greenschist metamorphism is ubiquitous, as cblorite-albitecarbonate-epidote alteration of primary mafic and feldspar minerals. Immobile element composition (figs. 5,6 ) indicate this unit formed as an intra-oceanic island arc. Compositional similarities to spatially associated gabbro blocks with serpentinite suggest that the units Dv, Dc, sp represent different structural levels within an island arc.

Dc Red and brown chert - Radiolarian chert, massive to well-layered, predominantly red, but also green and black. Locally manganiferous, with up to $0.5 \% \mathrm{MnO}$, and furruginous. Radiolaria indicate an upper Devonian age. Found bedded in the lower portions of the Devonian tuff (unit Dv), also as large fault blocks most notably in the drainage in southcentral portion of section 16, T20S, R11W.

DI Limestone - Medium- to thick-bedded, medium- to dark-gray lime mudstone to wackestone; locally fossiliferous with both rugose and tabulate corals, and brachiopods. Megafossils from the field area, as well as equivalent exposures in the Reindeer Hills, Healy C-4 quad.(Blodgett, 1977) indicate a Middle Devonian or slightly older age, although one locality in the field area yielded condonts identified as being of LateSiluian (latest Pridolian) or Early Devonian (Gedinnian, =Lochkovian) age (Jones and others, 1970).

uPzt Tuff - Described by Jones and others (1980) as unit JTr, part of the West Fork Terrane, this unit is characterized by predominantly dark grey-green, andesitic to rhyodacitic composition ash and crystal tuff, subordinate argillite, and cherty argillite, siltstone and greywacke, and minor volcanic flows. The ash tuff is commonly "flinty" and layered in 5 to $30 \mathrm{~cm}$ varicolored beds of green, white, and tan, and is clearly welded in places. Wispy layering is common within beds. The coarser crystal-lithic tuff occurs in thicker beds ( $>1$ meter), and hand specimens could be misidentified as sandstone. Basaltic- to andesiticcomposition, angular, clast-supported tuff breccias occur in poorly-exposed lower-elevation sites. Such rocks are compositionally indistinguishable from the mafic volcaniclastic rocks of unit $\mathrm{Dv}$ (figs. 5, 6). The interlayered sedimentary rocks are principally volcaniclastic sandstones, which appear to be reworked uff from the same sequence. Compositional and texnural similarities between this unit and unit Dv (figs. 5,6) suggest that unit uPzt represents the upper (felsic tuff-dominant) portion of Dv, partly removed during early Carboniferous erosion prior to deposition of unit PPs. Consequently, we infer that the "West Fork terrane" of Jones and others (1980) is indistinguishable from the Paleozoic rocks in the Chulitna region. 
uPzst Argillite and tuif - with lesser siltstone and chert. Compositions and character of the varying rock types are the same as uPzt, although the relative proportions are different. In this area, sedimentary rocks comprise about $85 \%$ of the unit, volcanic tuffs about $15 \%$. The contact with uPzst is transitional, and placed where sedimentary rocks are more abundant than tuffaceous rocks. We infer that this unit is largely equivalent to unit PPs.

uPzs Chert, argillite and graywacke - "Broad Pass" part of Jones and others (1980) Broad Pass terrane and Csejety and others (1992) Cretaceous melange. This unit is poorly-exposed, and includes a variety of lithologies found in steeply incised drainages where continuous traverses are not feasible. Lithologies encountered included bedded chert (upper Paleozoic based on radiolarians, Jones and others, 1980) and carbonaceous, fissile black argillite with yellow and orange-weathering salts, basalt, cherty tuff, green volcaniclastic rock, siltstone, graywacke (with black and occasionally red chert grains) and clastsupported, white quartz-pebble, black argillite (occasionally red argillite) conglomerate. Initial chemistry correlates a basalt from this region to unit Dv. Light green siliceous hornfels found locally in Ohio Creek canyon was originally thought to be flinty tuff, but major oxide analysis $(98 \mathrm{KCl} 45$, Gage and others, 1998) suggest this is sedimentary. Limestone crops out in Copeland Creek and Long Creek canyons and contains fossils thought to be identical to a Givetian (late Middle Devonian) fauna from Healy B-4 quadrangle described by Blodgett (1977). A narrow, northeast-trending aeromagnetic high traverses the unit and in three locations coincides with outcrops of very magnetic serpentinite as found to the northwest associated with unit DV. Based on similar lithologies, upper Paleozoic fossils and the serpentinite trend, this "unit" may represent a structural repetition of the upper Paleozoic rocks found to the northwest.

\section{Rocks of unknown age}

sp Serpentinite gabbro and silica-carbonate rocks - Mixed unit varying from intensely serpentinized, chromite-bearing dunite to altered gabbro. Generally occurs as tectonic lenses occupying the hinge zones of antiforms and along faults separating Devonian (?) volcanic (unit Dv) from Pennsylvanian-Permian volcanic and sedimentary units. Devonian age suggested due to common spatial proximity with Devonian chert unit, but age is not well-constrained. Serpentinite is commonly altered to silica-carbonate rock and is otherwise strongly magnetic. Gabbro is commonly layered, and varies from fine- to coarse-grained and from leucocratic to melanocratic altered clinopyroxene-plagioclase rock. Plagioclase is ubiquitously altered to clinozoisite-albite-sericite and pyroxene to chlorite-carbonate-epidote. Major and trace element similarities of the gabbro to basaltic members of the Devonian(?) volcaniclastic unit (Dv) suggest that the gabbros were feeders for the Devonian volcanics.

sp* Aeromagnetic high - This map unit is delineated by a narrow, strong magnetic signature that trends northeast through Broad Pass. Serpentinite was found in three locations in this area of little bedrock exposure and the unit is believed to be very similar to unit sp above.

\section{IGNEOUS ROCKS}

$\mathrm{Tg} \quad$ Biotite granite, mostly 50-55 Ma. - Textures range from fine-grained porphyritic (dikes) to coarsegrained, sub-equigranular. Normative compositions indicate most rocks are classified as alkali feldspar granite and lesser syeno-granite (fig. 7). Locally altered to tourmaline-zinnwaldite + biotite granite. Generally ilmenite series, lacking primary magnetite and sphene. Minor phases include topaz, zircon, apatice, and fluorite. Trace element data (fig. 8) indicate the rocks are highly fractionated members of collision-or extension-related felsic magmas. Narrow basaltic or lampropheric dikes (Tb) commonly intrude these bodies, generally at a scale which cannot be shown on the map.

Tb Basaltic-composition dikes of early Tertiary age - Invariably narrow ( $0.3-2 \mathrm{~m}$ wide), fine-grained, dark-colored, mafic dikes which cut Tertiary granites and locally cut all pre-Tertiary units. Most readily distinguished in the field by rare clinopyroxene phenocrysts, up to $2 \mathrm{~cm}$ in size, and by occurrence with 


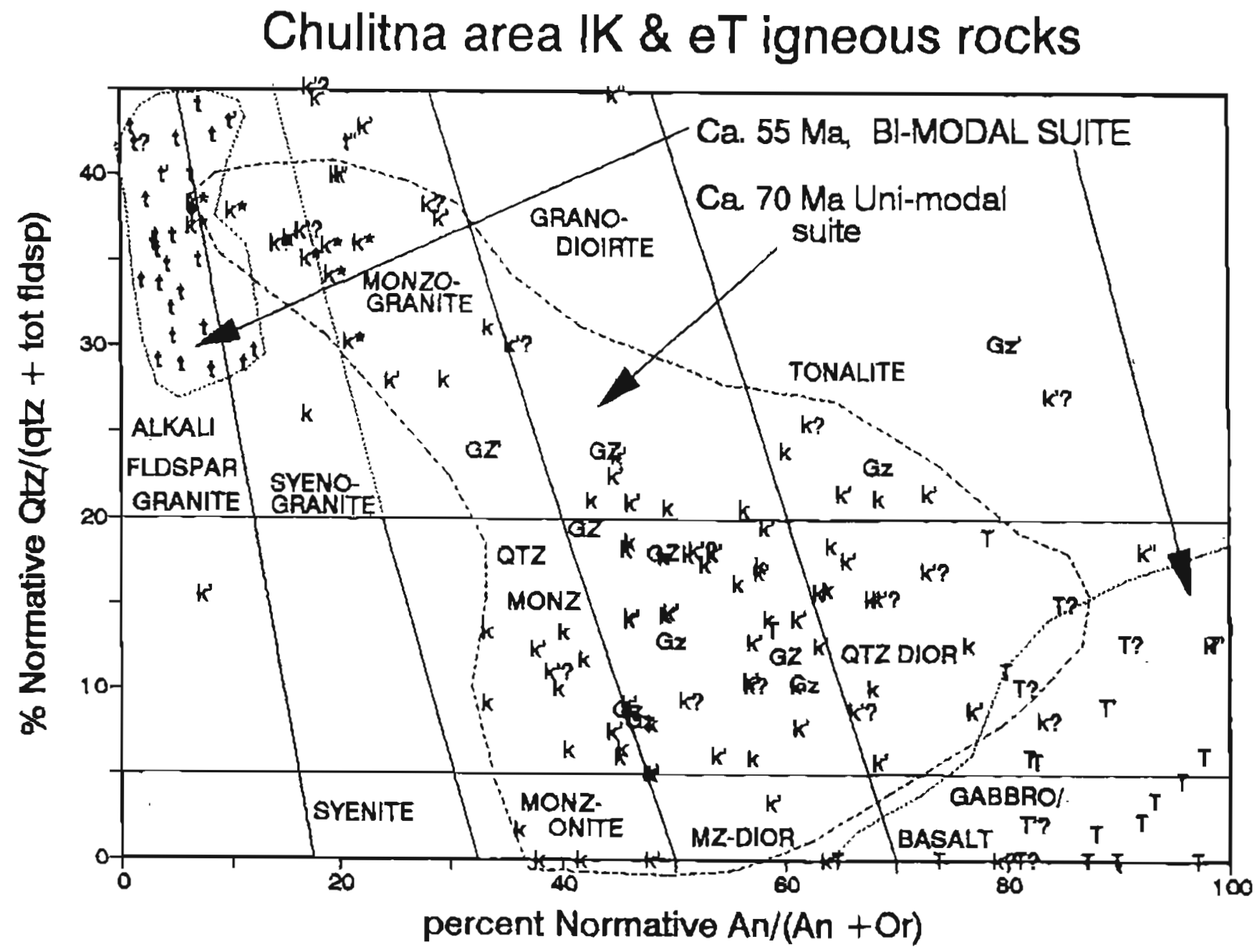

Fig. 7. Normative rock type classification diagram for late Cretaceous and early Tertiary intrusive rocks, after Streckeisen and LeMaitre (1979). Symbols: $k=$ late Cretaceous maficintermediate rock, $\mathrm{k}^{*}=$ late Cretaceous felsic rock; $\mathrm{t}=$ early Tertiary felsic rock, $\mathrm{T}=$ eariy Tertiary mafic rock, " = chemically altered, " = very altered, ? = age assignment based on rock composition (field relationships are ambiguous). Data from Hawley and Clark (1974), Wamer and Dahlin (1989), Kurtak (1992), Parker (1991), Newberry and Solie (1995), and Gage and others (1998). 


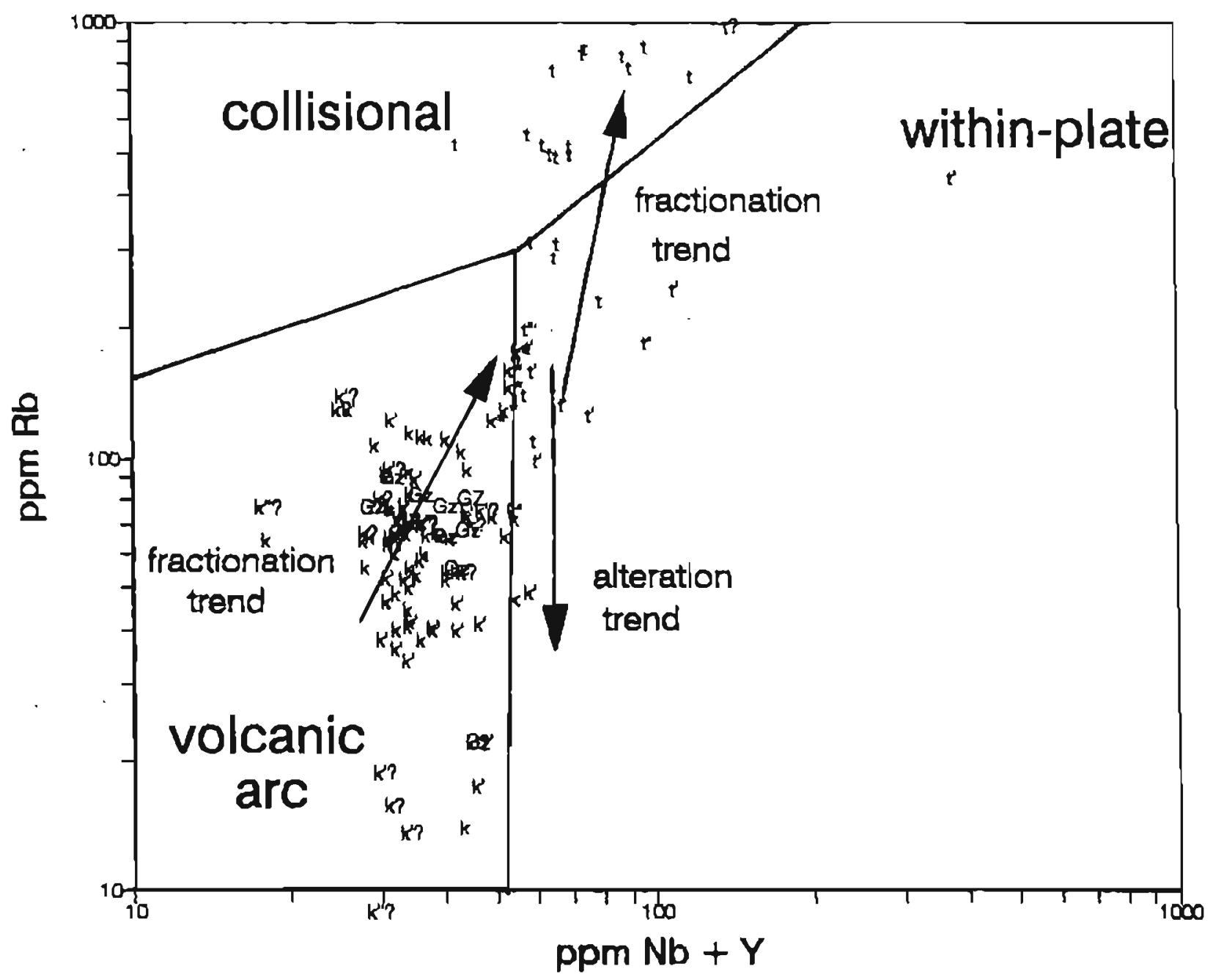

Fig. 8. Trace element data for late Cretaceous and eariy Tertiary granitic composition rocks piotted on the granitoid tectonic setting classification diagram of Pearce and others (1984). Note the higher incompatible element $(\mathrm{Nb}, \mathrm{Y}, \mathrm{Rb}$ ) contents of Tertiary granite samples relative to late Cretaceous granites and the gradational change in trace element contents from intermediate- to felsic-composition Cretaceous rocks. Symbols and data sources as in Fig. 7. 
Tertiary granite. Major and minor element compositions indicate these are exclusively of basalt composition, and some are alkali basait (figs. 4, 7). These rocks typically possess magnetic susceptibilities intermediate between those of Trb and $\mathrm{Km}$. Immobile element compositions indicate an extensional-related setting (figs. 5,6); most likely they represent the mafic member of an early Tertiary bi-modal magmatic suite.

$\mathrm{Km}$ Intermediate composition plutonic rocks with ages of 67 to $76 \mathrm{Ma}$. - Compositions are dominantly quartz monzodiorite, but quartz diorite, quartz monzonite, and granodiorite are also present (fig. 7). Despite their generally quarzz-poor character, trace element contents indicate a volcanic arc-related origin (fig. 8). ${ }^{40} \mathrm{Ar}{ }^{39} \mathrm{Ar}$ dating of these rocks and their homfels zones (table 1) indicates a spread of ages from $67 \mathrm{Ma}$ to $76 \mathrm{Ma}$; some of the younger ages have been thermally reset and the true age spread is likely narrower. Most $\mathrm{Km}$ dikes are easily recognized in the field by their distinctive homblende phenocrysts. Fine-grained and mafic varieties of $K \pi$ are distinguished from mafic dikes of units $T$ sb and $T b$ by distinctive immobile element contents (figs. 5,6 ) and their low magnetic susceptibility. Similarities in age (ca. $70 \mathrm{Ma}$ ) as well as major and minor element compositions (Szumigala, 1992; McCoy et al., 1997) suggest that this igneous suite represents the same late Cretaceous, intermediate composition magmatic event as the gold-related Kuskokwim Mountains magmatic belt of southwest Alaska

Bodies of $\mathrm{km}$ range in size from small stocks to narrow dikes, typically oriented northeast-southwest. Rock textures vary considerably, from fine-grained porphyritic to medium-grained, sub-equigranular. The dominant mafic mineral is hornblende; biotite is common in more felsic, and clinopyroxene in more mafic, varieties. Minor to major chlorite-carbonate-sericite-albite-epidote-pyrite (propylitic) alteration is common. Generally ilmenite series, i.e., lacking primary magnetite and sphene. Minor phases include zireon, allanite, and apatite.

Kg Late Cretaceous (hornblende) biotite granite - Monzo- and syeno-granite composition rocks (fig. 7) with ${ }^{40} \mathrm{Ar} /{ }^{39} \mathrm{Ar}$ minimum ages (table 1 ) of $>59$ to $>71 \mathrm{Ma}$

\section{ACKNOWLEDGMENTS}

C.C. Hawley shared his expertise on the geology, mineral deposits and mining history of the Chulitna district in addition to providing accommodations. Several University of Alaska Fairbanks students contributed to the project: Sara Haug assisted in the field, Adam Low provided a report on existing titerature and geophysical interpretarions, Paul Chu compiled our geochemical data and Ben Gage contributed to many aspects of the project and shared his own graduate work on the Golden Zone deposit. Paleontologic identifications were provided by M.Z. Won and Paula Noble (radiolarians), Chris McRoberts, Michael Sandy and George Stanley (Mesozoic megafossils) and Norman Savage (conodonts). David Stone with students Howard Scher and Chad Schopp conducted paleomagnetic studies. Paul Layer and Jeff Drake with the University of Alaska Geochronology Lab, provided ${ }^{40} \mathrm{Ar}{ }^{\beta 9} \mathrm{Ar}$ geochronology.

Partial funding for this project was provided through U.S. Geological Survey STATEMAP Cooperative Agreement 98HQAG2083. 


\section{REFERENCES CITED}

Alaska Division of Geological \& Geophysical Surveys, $1997,7200 \mathrm{~Hz}$ resistivity contours of the Chulitna mining district, Alaska: Alaska Division of Geological \& Geophysical Surveys Report of Ynvestigations 97-4, I sheet, full color, scale $1: 63,360$.

Alaska Division of Geological \& Geophysical Surveys, 1997, $900 \mathrm{~Hz}$ resistivity contours of the Chulitna mining district, Alaska: Alaska Division of Geological \& Geophysical Surveys Report of Investigations 97-3,1 sheet, full color, scale $\{: 63,360$.

Alaska Division of Geological \& Geophysical Surveys, 1997, Total field magnetics and electromagnetic anomalies of the Chulima mining districh, Alaska: Alaska Division of Geological \& Geophysical Surveys Report of Investigations 97-1, 1 sheet, 3 colors, scale 1:63,360.

Alaska Division of Geological \& Geophysical Surveys, 1997, Total field magnetics of the Chulitra mining district, Alaska: Alaska Division of Geological \& Geophysical Surveys Report of Investigations 97-2, 1 sheet, full color, scale 1:63,360.

Balen, M.D., 1990, Geochemical sampling results from Bureau of Mines Investigations in the Valdez Creek Mining District, Alaska: U.S. Bureau of Mines Open-File Report 34-90, 218 p.

Blodgett. R.B., 1977, A. Givetian (late Middle Devonian) fauna from Healy B-4 Quadrangle, central Alaska Range, Alaska: Alaska Division of Geological \& Geophysical Surveys, Short Notes on Alaska Geology, 1977, p. 1, 2.

Blodgeth, R.B., and Clautice, X.H., 1999, Fossil locality map and table, Healy A-6 Quadrangle, south-central Alaska: Alaska Division of Geological \& Geophysical Surveys Raw-Data File 1999-1, 36 p., 1 plate, scale $1: 63,360$.

Brooks, A.H., and Prindle, L.M., 1911, The Mount McKinley region, Alaska: U.S. Geological Survey Professional Paper 70, 234 p., scale 1:625,000.

Burns, L.E., 1997, Portfolio of aeromagnetic and resistivity maps of the Chulitna mining district: Alaska Division of Geological \& Geophysical Surveys Public-Data File Report 97-7, 13 p.

Capps, S.H., 1919, Mineral resources of the upper Chulitna region: U.S. Geological Survey Bulletin 692, p. $207-$ 232.

Clark, A.L., Clark, S.H.B, and Hawley, C.C.. 1972, Significance of upper Paleozoic oceanic crust in the upper Chulitna district, west-central Alaska Range: U.S. Geological Survey Professional Paper 800-C, p. C95-C101.

Csejtey, Béla, Jr., Mullen, Michael W., Cox, Dennis P., and Stricker, Gary D., 1992, Geology and geochronology of the Healy Quadrangle, south-central Alaska: U.S. Geological Survey Map I-1961, 63 p., scale 1:250,000, 2 sheets.

Csejtey, Béla, Jr., Cox, D.P., Evarts, R.C., Stricker, G.D., and Foster, H.L., 1982, The Cenozoic Denali fault system and the Cretaceous accretionary development of southem Alaska: Joumal of Geophysical Research, v. 87, no. B5, p 3,74!-3,754.

Csejtey, Bela, Jr., Nelson, W.H., Jones. D.L., Silberling, N.J., Dean, R.M., Mortis, M.S., Lanphere, M.A., Smith, J.G., and Silberman, M.L., 1978, Reconnaissance geologic map and geochronology, Talkeetna Mountains quadrangle, northem part of Anchorage quadrangle, and southwest comer of Healy quadrangle, Alaska: U.S. Geological Survey Open-File Reporr 78-558A, 62 p., scale 1:250,000.

Foley, J.Y., Burns, L.E., Schneider, C.L., and Forbes, R.B., 1989, Preliminary Report of platinum group element occurrences in Alaska, $33 \mathrm{p}$. 
Gage, B.. Chu. P., Liss, S.A., and Clautice. K.H., 1998. Preliminary geochemical and major oxide data: Chulima project, Healy A-6 Quadrangle and nearby area (1997 \& 1998 data): Alaska Division of Geological \& Geophysical Surveys Public-Data File 98-36. 48 p., 2 sheets, scale 1:63,360.

Hawley, C.C., 1994, Golden Zone Au Deposit. in Plafker, George, and Berg, Henry C., eds., The Geology of Alaska: The Geological Society of America. v. G-I, p. 878.

Hawley, C.C., and Clark, A.L., 1974, Geology and mineral deposits of the Upper Chulitna district, Alaska: U.S. Geological Survey Professional Paper 758-B. p. B1-B47, scales 1:48,000, 1:24,000, and 1:12,000.

Hawley, C.C., and Clark, Allen L., 1973, Geology and minera! deposits of the Chulitna-Yentna Mineral Belt, Alaska: U.S. Geological Survey Professional Paper 758-A, p. A1-A10, 2 sheets, 1:250,000, 1:500,000 scale.

Hawley, C.C., Clark, A.L., Herdrick. M.A., Clark, S.H.B., 1969, Results of geological and geochemical investigations in an area northwest of the Chuliona River, central Alaska Range: U.S. Geological Survey Circular $617,19 \mathrm{p}$.

Hawley, C.C., and Clark, A.L., 1968, Occurrences of goid and other metals in the upper Chulitna district, Alaska: U.S. Geological Survey Circular 564, 21 p.

Hawley, C.C., Clark, A.L., and Benfer, J.A., 1968, Geology of the Golden Zone mine area, Alaska: U.S. Geological Survey Open-File Report 68-122 (305), 16 p., 1:2,400 scale.

Jones, D.L., Silberłing, N.J., Csejtey, Béla. Jr.. Nelson, W.H., and Blome, C.D., 1980, Age and structural significance of ophiolite and adjoining rocks in the upper Chulitna district, south-central Alaska: U.S. Geological Survey Professional Paper 1121-A, p. A.1-A21, 2 plates in text, 1 sheet, scale 1:63,360.

Kurtak, J.M., Southworth, D.D., Balen, M.D., and Clautice, K.H., 1991, Mineral investigations in the Valdez Creek mining district, south-central A laska: U.S. Bureau of Mines OFR I-92,658 p.

Layer, P.W., Hall, C.M. \& York, D., 1987. The derivation of ${ }^{40}$ Ar $/{ }^{39} \mathrm{Ar}$ age spectra of single grains of hornblende and biotite by laser step heating, Geophys. Res. Lett., 14, 757-760.

Light, T.D., Tripp, R.B., and King, H.D., 1990. Interpretation of reconnaissance geochemical data from the Healy Quadrangle, Alaska: U.S. Geological Survey Bulletin 1894, 36 p.

MacKeveth, E.M., Jr., Cox, Dennis P., Potter, Robert W., and Silbennan, Miles L., 1997, Kennecont-type deposits in the Wrangell Mountains, Alaska: High-grade copper ores near a basalt-limestone contact: Economic Geology Monograph 9, p. 66-89.

McCoy, D., Newberry, R.J., Layer, P., DiMarchi, J.J., Bakke, A., Masternan, J.S. and Minehane, D.L., 1997, Plutonic related gold deposits of Interior Alaska, in Goldfarb, R.J., and Miller, L.D., eds., Mineral Deposits of Alaska, Economic Geology Monograph 9, p. 191-241.

Meinert, L.D., 1992, Skams and Skarn Deposits, Geoscience Canada v. 19, p. 1-23.

Moffit, F.H., 1915, The Broad Pass region, Alaska, with sections on Quaternary deposits, igneous rocks, and glaciation by J.E. Pogue: U.S. Geological Survey Bulletin 608, 80 p., scale 1;250,000.

Mulligan, J.J., Warfield, R.S., and Wells, R.R., 1967, Sampling a gold-copper deposit, Golden Zone mine, southcentral Alaska: U.S. Bureau of Mines open file report 9-67.

Newberry, R.J., 1995, An update on skam deposits of Alaska: Alaska Division of Geological \& Geophysical Surveys, Public-data File $95-20,87 \mathrm{p}$.

Newberry, R.J. and Solic, D.N., 1995, Data for plutonic rocks and associated gold deposits in Interior Alaska: Alaska Division of Geological \& Geophysical Surveys Public-data File 95-25, 62 p. 
Newberry, R.J., Allegro, G.L., Cutler, S.E., Hagen-Levelle, S.H., Adams, D.D., Nicholson, L.C., Wegiarz, T.B., Bakke, A.A., Clautice, K.H., Coulter, G.A., Ford, M.J., Myers, G.L., and Szumigala, D.J., 1997, Skam Deposits of Alaska, in Goldfarb, R.J., and Miller, L.D., eds., Mineral Deposits of Alaska, Economic Geology Monograph 9, p. 355-395.

Nichols, K.M., and Silberling, N.J., 1979, Early Triassic (Smithian) ammonites of paleoequatorial affinity from the Chulitna terrane, south-central Alaska: U.S. Geological Survey Professional Paper 1121-B, 5 p.

Nokleberg, W.J., Plafker, George, and Wilson, F.H., 1994, Geology of south-central Alaska, in Plafker, George, and Berg, H.C., eds., The Geology of North America, The Geology of Alaska: Geological Society of America, G-1, p. 311-366.

Pearce, J.A., and Cann, J.R., 1973, Tectonic serting of volcanic rocks determined using trace element analyses: Earth and Planetary Science Letters, v. 19, pp. 290-300.

Pearce, J.A., Harris, N.B.W., and Tindle, A.G., 1984, Trace element discrimination diagrams for the tectonic interpretation of granitic rocks: Journal of Petrology, v. 25, p. 956-983.

Reed, B.L., and Nelson, S.W., 1980, Geologic map of the Talkeetna quadrangle, Alaska: U.S. Geological Survey Miscellaneous Investigations Series Map 1-1 174, scale 1:250,000.

Reger, R.D., and Pinney, D.S., 1996, Late Wisconsin glaciation of the Cook Inlet region with emphasis on Kenai Lowland and implications for early peopling, in Davis, N.Y., and Davis, W.E., eds., Adventures through time: Readings in the anthropology of Cook Inleh, Alaska: Anchorage, Cook Inlet Historical Society, p. 15-35.

Ross, Clyde P., 1933, Mineral deposits near the West Fork of the Chulima River, Alaska: U.S. Geological Survey Bulletin 849-E, p. 289-333, 1 sheet, scale 1:125,000.

Samson, S.D., and Alexander, E.C., 1987, Calibration of the interlaboratory ${ }^{40} \mathrm{Ar}-{ }^{39} \mathrm{Ar}$ dating standard, MMhb-1: Chemical Geology, v. 66, p. 27-34.

Silberling, N.J., Jones, D.L., Csejtey, B., Jr., and Nelson, W.H., 1978, Interpretive bedrock geologic map of part of the upper Chulitma district, Healy A-6 Quadrangle, Alaska Range, Alaska: U.S. Geological Survey Open-File Report 78-545, 1 sheet, scale 1:63,360.

Steiger, R.H. and Jaeger, E., 1977, Subcommission on geochronology: Convention on the use of decay constants in geo and cosmochronology: Earth and Planet Science Letters, v. 36, p. 359-362.

Stone, David, Scher, Howard, and Schopp, Chad, 1999, Chulitna-area paleomagnetic studies: Alaska Division of Geological \& Geophysical Surveys Raw-Data File 1999-2, 3 p.

Streckeisen, A.L., and LeMaitre, R.W., 1979, A chemical approximation to the modal QAPF classification of the igneous rocks: Neues Jahrbuch fur Mineralogie Abhandlungen,,v. 136, p. 169-206.

Swainbank, R.C., Smith, T.E., and Tumer, D.L., 1977, Geology and K-Ar age of mineralized intrusive rocks from the Chulitna mining district, central Alaska, in Short notes on Alaskan Geology - 1977: Alaska Division of Geological \& Geophysical Surveys, Geologic Report 55, p. 23-28.

Szumigala, D.J., 1993, Gold mineralization related to Cretaceous-Tertiary magmatism in the Kuskokwim Mountains of west-central and soutbwestern Alaska: Unpublished Ph.D. dissertation, Los Angeles, Califomia, University of Califomia, $301 \mathrm{p}$.

Ten Brink, N.W., 1983, Glaciation of the northern Alaska Range, in Thorson, R.M, and Hamilton, T.D., eds., Glaciation in Alaska: Extended abstracts from a workshop: Alaska Quaternary Center, University of Alaska Museum Occasional Paper No. 2, p. 82-91.

Wahrhaftig, Clyde, and Black, R.F., 1958, Engineering geology along part of the Alaska Railroad: U.S. Geological Survey Professional Paper 293-B, p. 79-118, 6 sheets, scale 1:63,360. 
Warner, Dean J, and Dahlin, D., 1989, Tin occursences associated with the Ohio Creek pluton, Chulitna region, south-central Alaska: U.S. Bureau of Mines Open-File Report 5-89, 29 p.

Winchester, J.A. and Floyd, P.A., 1977, Geochemical discrimination of different magma series and their differentiation products using immobile elements: Chemical Geology, vol. 20, p. 325-343.

Won, M.Z., Blodgett, R.B., Clautice, K.H., and Newberry, R.J., 1999, Late Devonian (late Famennian) radiolarians from the Chulitna rerrane, south-central Alaska: Alaska Division of Geological \& Geophysical Surveys, Short Notes on Alaska Geology 1999 (in press). 